\title{
Y-12 Sustainable Design Principles For Building Design and Construction
}

\author{
November 2008
}

Compiled By:

Y-12 Waste Management

\author{
Prepared by: \\ Babcock \& Wilcox Technical Services Y-12, LLC \\ Management \& Operating Contractor \\ For the \\ Y-12 National Security Complex \\ Under contract DE-AC05-000R22800 \\ With the \\ U.S. Department of Energy \\ National Nuclear Security Administration
} does not consthufe olearance for Public Relesse.

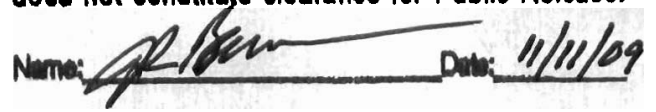




\section{Disclaimer}

This report was prepared as an account of work sponsored by an agency of the United States Government. Neither the United States Government nor any agency thereof, nor any of their employees, makes any warranty, express or implied, or assumes any legal liability or responsibility for the accuracy, completeness, or usefulness of any information, apparatus, product, or process disclosed, or represents that its use would not infringe privately owned rights. Reference herein to any specific commercial product, process, or service by trade name, trademark, manufacturer, or otherwise, does not necessarily constitute or imply its endorsement, recommendation, or favoring by the United States Government or any agency thereof. The views and opinions of authors expressed herein do not necessarily state or reflect those of the United States Government or any agency thereof. 
Y/TS-1996/R1

\title{
Y-12 Sustainable Design Principles For Building Design and Construction
}

\author{
Y-12 Sustainability and Stewardship \\ Jan Gilbert Jackson
}

November 2008

\author{
B\&W Y-12, L.L.C. \\ Y-12 Waste Operations
}

Prepared by the Oak Ridge Y-12 National Security Complex

Oak Ridge, Tennessee 37831

Managed by

B\&W Y-12, L.L.C.

For the U.S. Department of Energy

Under contract DE-AC05-00OR22800 


\section{$\underline{\text { Y-12 Sustainable Design Principles for Building Design and Construction }}$}

$\mathrm{B} \& \mathrm{~W} \mathrm{Y}-12$ is committed to modernizing the $\mathrm{Y}-12$ complex to meet future needs with a sustainable and responsive infrastructure and to integrating sustainability principles and practices into Y-12 work (Y72-001, B\&W Y-12 Environmental, Safety and Health Policy This commitment to sustainability and specifically sustainable design of buildings is also incorporated into Presidential Executive Orders (EO), DOE Orders (DOE O), and goals. Sustainable building design is an approach to design, construct, and operate facilities in an efficient and environmentally sound manner that will produce a healthful, resourceefficient and productive working environment that is inherently protective of the environment.

The DOE has established the following 5 Guiding Principles for High Performance Sustainable Building (HPSB), and has issued directives that require Y-12 to incorporate the principles and a number of supporting specific practices and techniques into building design, construction and renovation projects:

1. Employ Integrated Design Principles

2. Optimize Energy Performance

3. Protect and Conserve Water

4. Enhance Indoor Environmental Quality

5. Reduce Environmental Impact of Materials

The purpose of this document is to present the required sustainable building principles, practices and techniques, summarize the key drivers for incorporating them into Y-12 projects, and present additional recommendations and resources that can be used to support sustainable buildings to enhance the environmental and economic performance of the Y-12 Complex.

The required principles, practices, and techniques are primarily established in three DOE Orders (DOE O) which are included in Y-12's contractual requirements: DOE O 413.3A, Program and Project Management for the Acquisition of Capital Assets; DOE O 430.2B, Departmental Energy and Utilities Management; and DOE O 450.1A, Environmental Protection Program.

- DOE O 413.3A specifically requires the application of the HPSB principles to the siting, design, construction, and commissioning of new facilities and major renovations of existing facilities. The HPSB principles and specific practices and techniques required to support the principles are defined in a Memorandum of Understanding on Federal Leadership in High Performance and Sustainable Buildings that is referenced in this DOE Order.

- DOE O 430.2B establishes additional sustainable design requirements for major building construction and renovations (exceeding $\$ 5$ million) by requiring these projects to attain Leadership in Energy and Environmental Design (LEED) Gold certification. All other building and renovation projects must incorporate the HPSB principles and their related practices and techniques. DOE O 430.2B also 


\section{$\underline{\text { Y-12 Sustainable Design Principles for Building Design and Construction }}$}

sets requirements to meet leadership goals (established in EO 13423, Strengthening Federal Environmental, Energy and Transportation Management) for incorporating sustainable design principles into existing buildings, energy efficiency, use of renewable energy and water conservation, purchasing energy efficient products and equipment, and advancing the nation's energy security which are also drivers for sustainable building practices and techniques included in this document.

- DOE O 450.1A establishes sustainable environmental stewardship goals to be supported by Y-12 activities that require use of environmentally preferable products, eliminating ozone depleting compounds (ODC), recycling construction debris, and implementing and maintaining recycling programs in all facilities at the Y-12 Complex. This order sets requirements to meet EO 13423 leadership goals for recycling, waste reduction, pollution prevention, toxics use reduction and environmentally preferable procurement.

The sustainable building principles included in this document closely mirror the HPSB principles, practices and techniques that are required by DOE O 413.3A and DOE O 430.2B. A few additional practices and techniques that are required by other DOE and Executive Orders and Y-12 procedures, or are prerequisites for achieving LEED certification are also presented in this document.

Table 1 presents the required sustainable building principles and practices, techniques and key drivers that establish and define the requirements for Y-12 building projects. In addition, the table includes recommended techniques that may be incorporated to improve building environmental and economic performance, and to help attain the credit points required to achieve LEED Gold certification. The LEED prerequisites that must be met to be eligible for certification are also identified as 'Required' techniques in the table (These prerequisites will be requirements for construction and renovation projects that meet the definition included in $430.2 B$, i.e., greater than $\$ 5$ million unless an exemption is obtained)

NOTE: Although LEED Gold certification is a requirement that applies to Y-12's major construction and renovation projects ( $>\$ 5$ million), this document does not include a complete list of criteria that will enable successful attainment of LEED Gold certification. This is due to the menu-driven nature of the LEED rating system and certification process. The LEED rating system contains both a list of seven prerequisites that must be satisfied to be eligible for certification, and a variety of 'extra credit' criteria that may be pursued in order to gain the points necessary to meet the Gold level of certification. (To achieve a Gold level of LEED certification, a building must incorporate enough sustainable design features to achieve at least 39 LEED credit points based on the LEED Credit criteria established by the US Green Building Council.) The selection of specific credit points to pursue for any given project is flexible so a complete listing of required LEED credits and their criteria is impossible to assemble and is therefore outside the scope of this document. Project teams should enlist the help of a LEED Accredited Professional, use this document and Table 1 as a resource for identifying potential credits to pursue, and consult the LEED resources listed below when developing a strategy for LEED Gold certification. 


\section{$\underline{\text { Y-12 Sustainable Design Principles for Building Design and Construction }}$}

Section I that follows Table 1 presents additional discussion and resources that may be useful in pursuing sustainable building principles, practices and techniques. Section II summarizes the key sustainable building driver(s) that currently apply to B\&W Y-12 construction projects.

Additional information on sustainable design and green building practices is available from the following resources and other resources listed in Section I:

- DOE G 413.3-6 High Performance Sustainable Building. This Guide highlights the DOE O 413.3A drivers for incorporating HPSB principles into Critical Decisions 1 through 4, provides guidance for implementing DOE O 413.3A HPSB requirements, and provides tools that can be used to determine the relationship between the USGBC LEED certification criteria and the HPSB requirements (to facilitate attainment of LEED Gold certification that DOE O 430.2B requires for major renovations and capital asset construction). This guide is available on line at www.directives.doe.gov

- $\quad$ The Whole Building Design Guide (www.wbdg.org) and the Whole Building Design Guide's Executive Order (E.O.) 13423 Technical Guidance for Implementing the Five Guiding Principles for Federal Leadership in High Performance and Sustainable Buildings webpage (http://www.wbdg.org/sustainableEO/index.php) provide a variety of background, technical, and other High Performance Sustainable Building (HPSB) resource information. The Whole Building Design Guide is maintained by the National Institute of Building Sciences, with support from over 25 Federal agencies (including the Department of Energy), private-sector companies, and non-profit organizations.

- U.S. Green Building Council's Leadership in Energy and Environmental Design (LEED) Green Building Rating System, www.usgbc.org, provides links to downloadable LEED certification criteria for New Construction projects (LEEDNC), and Existing Buildings (LEED-EB).

- Roadmap for Integrating Sustainable Design into Site-Level Operations, http://www.pnl.gov/main/publications/external/technical_reports/PNNL13183.pdf. The web-site provides strategies for DOE facilities to apply sustainable design principles to daily operations including research, production, and environmental restoration processes,

- U.S. DOE Office of Health, Safety and Security Sustainable Environmental Stewardship homepage offers several resources and tools to help incorporate the High Performance Sustainable Building principles into construction and renovation projects: https://www.hss.energy.gov/pp/leed.html\#DOE 


\section{$\underline{\text { Y-12 Sustainable Design Principles for Building Design and Construction }}$}

- U.S. DOE Office of Energy Efficiency and Renewable Energy High Performance Sustainable Building home page, www.eere.energy.gov. The page provides links to several useful sustainable design tools such as the Los Alamos National Laboratory Sustainable Design Guide and energy simulation software,

- National Institute of Standards and Technology Building for Environmental and Economic Sustainability, www.bfrl.nist.gov/oae/software/bees.html. This is a tool for selecting cost effective, environmentally preferable building construction products,

- The Sustainable Design page of the Y-12 Pollution Prevention (Sustainability and Environmental Stewardship) internal website contains links to many of the resources listed in this document, as well as: The ORNL Conceptual Landscape Plan \& Design Guidelines which contains a native plant list and includes environmentally beneficial landscape techniques for sustainable design, and; The Idaho National Laboratory (INL) Green Building Strategy which provides recommendations for sustainable building design broken into three levelsBaseline recommendations for all buildings, Leadership in Energy and Environmental Design (LEED) recommendations for pursuing certification, and Innovative recommendations. The guide also contains a checklist summary of the INL Green Building Strategies that can be used as a tool during the design process when considering which green building features to include. 


\section{$\underline{\text { Y-12 Sustainable Design Principles for Building Design and Construction }}$}

Table 1 Summary of Sustainable Building Principles, Practices, Techniques and Drivers

\begin{tabular}{|c|c|c|c|}
\hline $\begin{array}{l}\text { Sustainable } \\
\text { Building } \\
\text { Principle } \\
\text { (Required) }\end{array}$ & $\begin{array}{l}\text { Sustainable } \\
\text { Building } \\
\text { Practice(s) } \\
\text { (Required) }\end{array}$ & $\begin{array}{l}\text { Sustainable Building Techniques } \\
\text { (Refer to Section I of this document for resources) } \\
\text { *REQUIRED Techniques are shown in Bold font } \\
\text { Other /recommended techniques are shown in italics }\end{array}$ & Key Sustainable Building Drivers \\
\hline $\begin{array}{c}1 . \\
\text { Employ } \\
\text { Integrated } \\
\text { Design } \\
\text { Principles }\end{array}$ & $\begin{array}{c}\text { 1.a } \\
\text { Use a } \\
\text { collaborative } \\
\text { and integrated } \\
\text { planning and } \\
\text { design process }\end{array}$ & $\begin{array}{l}\text { - Initiate and maintain an integrated project team in all stages of a } \\
\text { project's planning and delivery, } \\
\text { - Establish performance goals for siting, energy, water, materials, and } \\
\text { indoor environmental quality along with other comprehensive design } \\
\text { goals, } \\
\text { - Ensure incorporation of above goals throughout the design and } \\
\text { lifecycle of the building, } \\
\text { - Consider all stages of the building lifecycle, including deconstruction. } \\
\text { - Use LEED Accredited Professional to assist with the design process } \\
\text { (1credit point available under LEED Innovation and Design Process } \\
\text { Credit 2). }\end{array}$ & $\begin{array}{l}D O E O \text { 413.3A requires contractors to apply high performance } \\
\text { sustainable building (HPSB) principles to siting, design, construction } \\
\text { and commissioning of new facilities and major renovations. The HPSB } \\
\text { principles are given in the January } 2006 \text { HPSB MOU and are detailed in } \\
D O E \text { G 413.3-6 Attachment A. } \\
\text { DOE O 430.2B requires capital asset and major renovation projects to } \\
\text { attain LEED Gold certification for all new construction and major } \\
\text { building renovations in excess of \$5 million. All buildings falling below } \\
\text { this threshold are required to comply with the Guiding Principles for } \\
\text { Federal Leadership in High Performance and Sustainable Buildings } \\
\text { (HPSB principles).. }\end{array}$ \\
\hline $\begin{array}{c}1 . \\
\text { Employ } \\
\text { Integrated } \\
\text { Design } \\
\text { Principles }\end{array}$ & $\begin{array}{c}\text { 1.b } \\
\text { Employ total } \\
\text { building } \\
\text { commissioning } \\
\text { practices }\end{array}$ & $\begin{array}{l}\text { - Tailor commissioning to size and complexity of the building and its } \\
\text { system components in order to verify performance of building } \\
\text { components and systems and help ensure that design requirements } \\
\text { are met, } \\
\text { - Include a designated commissioning authority, } \\
\text { - Include commissioning requirements in construction documents } \\
\text { - Develop a commissioning plan, } \\
\text { - Verify installation and performance of systems to be commissioned } \\
\text { - Create a commissioning report, } \\
\text { - Meet requirements of LEED Energy and Atmosphere Prerequisite 1: } \\
\text { Fundamental Commissioning of Building Energy Systems*. } \\
\text { - Meet additional commissioning requirements of LEED Energy and } \\
\text { Atmosphere Credit 3- Enhanced Commissioning to receive one point } \\
\text { toward LEED certification. }\end{array}$ & $\begin{array}{l}\text { DOE O 413.3A requires contractors to apply high performance } \\
\text { sustainable building (HPSB) principles to siting, design, construction } \\
\text { and commissioning of new facilities and major renovations. The HPSB } \\
\text { principles are given in the January } 2006 \text { HPSB MOU and are detailed in } \\
D O E \text { G 413.3-6 Attachment A. } \\
\text { DOE O 430.2B requires capital asset and major renovation projects to } \\
\text { attain LEED Gold certification for all new construction and major } \\
\text { building renovations in excess of \$5 million. All buildings falling below } \\
\text { this threshold are required to comply with the Guiding Principles for } \\
\text { Federal Leadership in High Performance and Sustainable Buildings } \\
\text { (HPSB principles). }\end{array}$ \\
\hline
\end{tabular}




\section{$\underline{\text { Y-12 Sustainable Design Principles for Building Design and Construction }}$}

\begin{tabular}{|c|c|c|c|}
\hline $\begin{array}{l}\text { Sustainable } \\
\text { Building } \\
\text { Principle } \\
\text { (Required) }\end{array}$ & $\begin{array}{l}\text { Sustainable } \\
\text { Building } \\
\text { Practice(s) } \\
\text { (Required) }\end{array}$ & $\begin{array}{l}\text { Sustainable Building Techniques } \\
\text { (Refer to Section I of this document for resources) } \\
\text { *REQUIRED Techniques are shown in Bold font } \\
\text { Other /recommended techniques are shown in italics }\end{array}$ & Key Sustainable Building Drivers \\
\hline $\begin{array}{c}2 . \\
\text { Optimize } \\
\text { Energy } \\
\text { Performance }\end{array}$ & $\begin{array}{c}\text { 2.a } \\
\text { Optimize } \\
\text { building energy } \\
\text { efficiency }\end{array}$ & 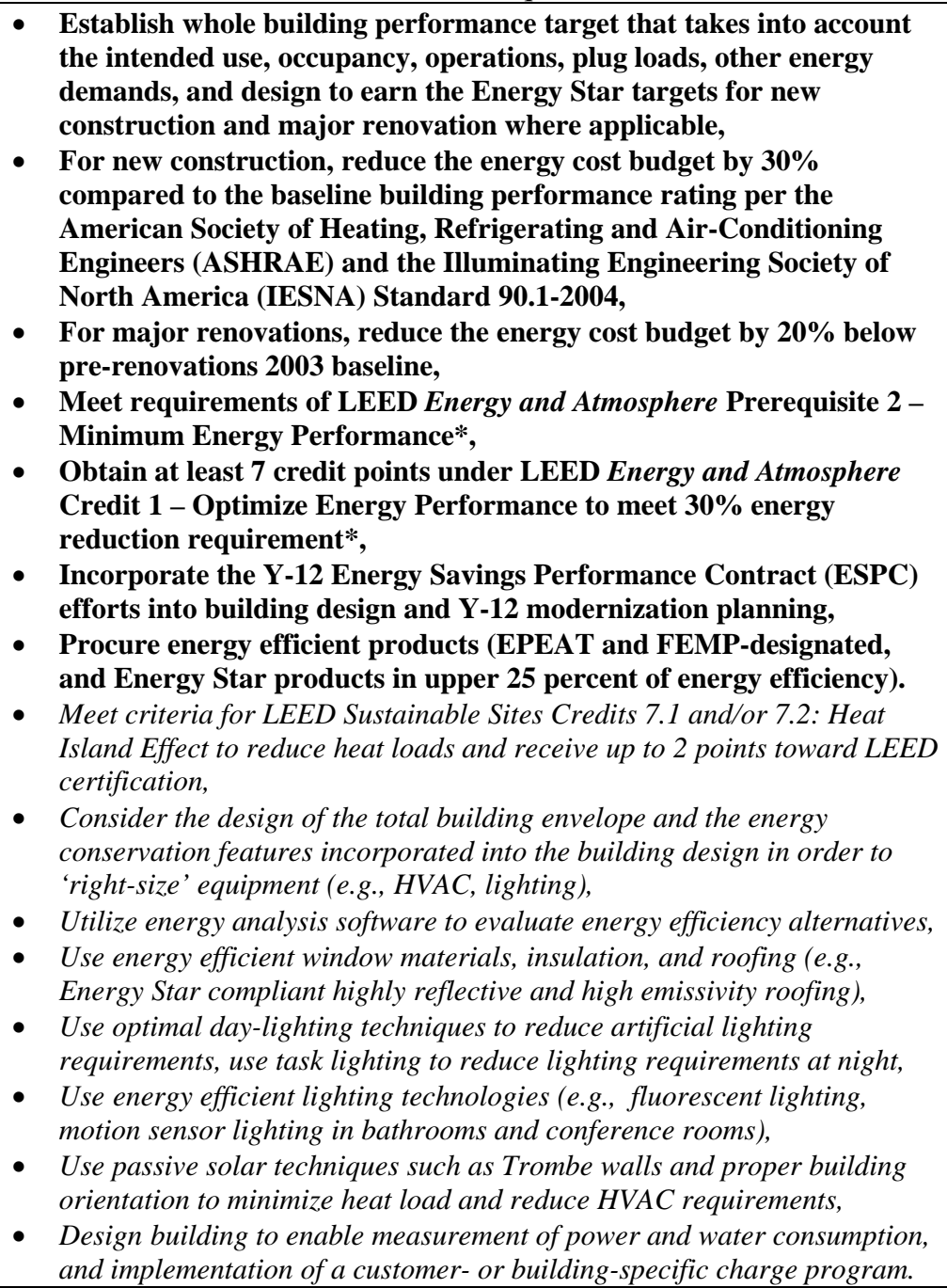 & $\begin{array}{l}\text { DOE O 413.3A requires contractors to apply high performance } \\
\text { sustainable building (HPSB) principles to siting, design, construction } \\
\text { and commissioning of new facilities and major renovations. The HPSB } \\
\text { principles are given in the January } 2006 \text { HPSB MOU and are detailed in } \\
D O E \text { G } 413.3-6 \text { Attachment A. } \\
\text { DOE O 430.2B requires capital asset and major renovation projects to } \\
\text { attain LEED Gold certification for all new construction and major } \\
\text { building renovations in excess of } \$ 5 \text { million. All buildings falling below } \\
\text { this threshold are required to comply with the Guiding Principles for } \\
\text { Federal Leadership in High Performance and Sustainable Buildings } \\
\text { (HPSB principles). } \\
\text { DOE O 430.2B requires employment of integrated design principles } \\
\text { including optimization of energy efficiency and use of renewable energy } \\
\text { in accordance with the HPSB principles and the other building and } \\
\text { construction-related E.O. } 13423 \text { goals and instructions; requires design } \\
\text { of buildings to meet or exceed Energy Star building criteria; } \\
\text { incorporation of ESPC efforts into building design, and procurement of } \\
\text { ENERGY STAR }{ }^{2} \text {-qualified or FEMP-designated products when } \\
\text { purchasing energy consuming products. This includes incorporation into } \\
\text { the specifications for all procurements involving energy consuming } \\
\text { products and systems, including guide specifications, project } \\
\text { specifications, and construction, renovation, and services contracts that } \\
\text { include provision of energy consuming products and systems or products } \\
\text { in upper } 25 \text { percent of energy efficiency. } \\
\text { EO } 13423 \text { sets goals for energy efficiency, acquiring electronic } \\
\text { products that are Electronic Product Assessment Tool (EPEAT)- } \\
\text { registered electronic products (unless there is no EPEAT standard for } \\
\text { such product) and to enable the Energy Star features on all agency } \\
\text { computers and monitors. } \\
D O E ~ O ~ 450.1 A \text { sets goals for procuring EPEAT products and enabling } \\
\text { Energy Star features on electronic equipment. }\end{array}$ \\
\hline
\end{tabular}




\section{$\underline{\text { Y-12 Sustainable Design Principles for Building Design and Construction }}$}

\begin{tabular}{|c|c|c|c|}
\hline $\begin{array}{l}\text { Sustainable } \\
\text { Building } \\
\text { Principle } \\
\text { (Required) }\end{array}$ & $\begin{array}{l}\text { Sustainable } \\
\text { Building } \\
\text { Practice(s) } \\
\text { (Required) }\end{array}$ & $\begin{array}{l}\text { Sustainable Building Techniques } \\
\text { (Refer to Section I of this document for resources) } \\
\text { *REQUIRED Techniques are shown in Bold font } \\
\text { Other /recommended techniques are shown in italics }\end{array}$ & Key Sustainable Building Drivers \\
\hline $\begin{array}{c}2 . \\
\text { Optimize } \\
\text { Energy } \\
\text { Performance }\end{array}$ & $\begin{array}{l}\text { 2.b } \\
\text { Enhance use of } \\
\text { renewable } \\
\text { energy sources }\end{array}$ & $\begin{array}{l}\text { Reduce building use of petroleum-based fuels and utilize renewable } \\
\text { energy where feasible and cost effective. } \\
\text { - Meet requirements of LEED Energy and Atmosphere Credit 2: On-site } \\
\text { Renewable Energy, and/or Credit 6: Green Power to earn up to } 4 \text { credit } \\
\text { points toward LEED certification, } \\
\text { - Use natural gas or ethanol instead of petroleum-based heating oils and } \\
\text { fuels, } \\
\text { - Purchase grid-source non-hydroelectric renewable energy 'green power' } \\
\text { (wind, solar, geothermal, and biomass technologies), } \\
\text { - Purchase electricity from less polluting generating plants such the TVA } \\
\text { - Green Power program, } \\
\text { - Incorporate off-grid generation systems such as solar hot water, solar } \\
\text { electric, solar outdoor lighting, small wind turbines, fuel cells, and } \\
\text { building-integrated photo-voltaic (BIPV) into building design. } \\
\text { Design buildings and parking structures to facilitate and promote a reduction } \\
\text { in the amount of petroleum-based energy required to move personnel to and } \\
\text { from Y-12, and within the Y-12 Complex. Techniques include: } \\
\text { - Meet requirements of LEED Sustainable Sites Credits } 4.1 \text { - } 4.4 \text { : Alternative } \\
\text { Transportation to earn up to } 4 \text { credit points toward LEED certification, } \\
\text { - Preferred parking spaces for employee carpools and for vehicles powered } \\
\text { by alternative-fuels, } \\
\text { - Provide on-site access to alternative fuels for Y-12 employees and the Y-12 } \\
\text { vehicle fleet, } \\
\text { - Provide inviting / sheltered seating area(s) for Y-12 shuttle user, } \\
\text { - Provide secure bicycle storage areas and convenient changing/shower } \\
\text { facilities to provide employees with the opportunity to bike to work instead } \\
\text { of drive, } \\
\text { - Provide bike racks within the Y-12 Complex. }\end{array}$ & $\begin{array}{l}\text { DOE O } 430.2 B \text { requires employment of integrated design principles } \\
\text { including optimization of energy efficiency and use of renewable energy } \\
\text { in accordance with the HPSB Guiding Principles and the other building } \\
\text { and construction-related E.O. } 13423 \text { goals and instructions } \\
\text { DOE O } 430.2 B \text { requires Y-12 to minimize use of petroleum-based fuels, } \\
\text { and increase use of renewable energy sources and off-grid generation } \\
\text { systems (such as solar hot water, solar electric, solar outdoor lighting, } \\
\text { etc.) and requires capital asset and major renovation projects to attain } \\
\text { LEED Gold certification and all other projects to incorporate HPSB } \\
\text { principles. } \\
\text { EO } 13423 \text { sets goals for increased use of renewable energy, and reduced } \\
\text { use of petroleum products. } \\
\text { DOE O } 450.1 A \text { requires procuring bio-based materials to minimize } \\
\text { pollution, and establishing goals to reduce environmental releases, } \\
\text { minimize use of toxic chemicals, and maximize environmental- } \\
\text { preferable purchases of bio-based materials. } \\
\text { The Y-12 Sustainability and Environmental Stewardship Program is } \\
\text { required to report Y-12 projects and accomplishments that support these } \\
\text { goals. }\end{array}$ \\
\hline
\end{tabular}




\section{Y-12 Sustainable Design Principles for Building Design and Construction}

\begin{tabular}{|c|c|c|c|}
\hline $\begin{array}{l}\text { Sustainable } \\
\text { Building } \\
\text { Principle } \\
\text { (Required) }\end{array}$ & $\begin{array}{l}\text { Sustainable } \\
\text { Building } \\
\text { Practice(s) } \\
\text { (Required) }\end{array}$ & $\begin{array}{l}\text { Sustainable Building Techniques } \\
\text { (Refer to Section I of this document for resources) } \\
\text { *REQUIRED Techniques are shown in Bold font } \\
\text { Other /recommended techniques are shown in italics }\end{array}$ & Key Sustainable Building Drivers \\
\hline $\begin{array}{c}2 . \\
\text { Optimize } \\
\text { Energy } \\
\text { Performance }\end{array}$ & $\begin{array}{l}\text { 2.c } \\
\text { Measure and } \\
\text { verify energy } \\
\text { consumption }\end{array}$ & $\begin{array}{l}\text { - Install building level utility meters in new major construction and } \\
\text { renovation projects to track and continuously optimize performance } \\
\text { (in accordance with DOE guidelines issued under section } 103 \text { of the } \\
\text { Energy Policy Act of 2005), } \\
\text { - Compare actual performance data from the first year of operation } \\
\text { with the energy design target, } \\
\text { - After one year of occupancy, measure all new major installations using } \\
\text { the Energy Star benchmarking Tool for the building and space types } \\
\text { covered by Energy Star, } \\
\text { - Enter data and lessons learned from sustainable buildings into the } \\
\text { DOE High Performance Buildings Database. } \\
\text { - Meet requirements of LEED Energy and Atmosphere Credit } 5 \text { - } \\
\text { Measurement \& Verification to achieve one credit point toward LEED } \\
\text { certification. }\end{array}$ & $\begin{array}{l}D O E O 413.3 A \text { requires contractors to apply high performance } \\
\text { sustainable building (HPSB) principles to siting, design, construction } \\
\text { and commissioning of new facilities and major renovations. The HPSB } \\
\text { principles are given in the January } 2006 \text { HPSB MOU and are detailed in } \\
D O E \text { G 413.3-6 Attachment A. } \\
\text { DOE O 430.2B requires capital asset and major renovation projects to } \\
\text { attain LEED Gold certification for all new construction and major } \\
\text { building renovations in excess of } \$ 5 \text { million. All buildings falling below } \\
\text { this threshold are required to comply with the Guiding Principles for } \\
\text { Federal Leadership in High Performance and Sustainable Buildings } \\
\text { (HPSB principles). }\end{array}$ \\
\hline $\begin{array}{c}3 . \\
\text { Protect and } \\
\text { Conserve } \\
\text { Water }\end{array}$ & $\begin{array}{c}\text { 3.a } \\
\text { Indoor- } \\
\text { Reduce indoor } \\
\text { water use } 20 \%\end{array}$ & $\begin{array}{l}\text { - Employ strategies that in aggregate use a minimum of } 20 \% \text { less } \\
\text { potable water than baseline calculated for the building after meeting } \\
\text { EPAct of } 1992 \text { fixture performance requirements, } \\
\text { - Where available, purchase WaterSense labeled products and other } \\
\text { water efficient products and choose irrigation contractors who are } \\
\text { certified through a WaterSense labeled program. } \\
\text { - Meet requirements of LEED Water Efficiency Credit 3.1 or 3.2: Water } \\
\text { Use Reduction } 20 \% \text { or } 30 \% \text { to receive up to } 2 \text { credit points toward LEED } \\
\text { certification. } \\
\text { - Lesign techniques include: } \\
\text { - Low flow or dual-flush toilets, } \\
\text { - Auto-cutoff sinks, } \\
\text { - Dry fixtures such as waterless urinals, } \\
\text { - Plumbing fixtures that exceed the requirements of the Energy Policy Act, } \\
\text { - Water-efficient cooling towers that use delimiters to reduce drift and } \\
\text { evaporation. }\end{array}$ & $\begin{array}{l}\text { DOE O 413.3A requires contractors to apply high performance } \\
\text { sustainable building (HPSB) principles to siting, design, construction } \\
\text { and commissioning of new facilities and major renovations. The HPSB } \\
\text { principles are given in the January } 2006 \mathrm{HPSB} M O U \text { and are detailed in } \\
D O E \text { G } 413.3-6 \text { Attachment A. } \\
\text { DOE O 430.2B requires capital asset and major renovation projects to } \\
\text { attain LEED Gold certification for all new construction and major } \\
\text { building renovations in excess of } \$ 5 \text { million. All buildings falling below } \\
\text { this threshold are required to comply with the Guiding Principles for } \\
\text { Federal Leadership in High Performance and Sustainable Buildings } \\
\text { (HPSB principles). } \\
\text { DOE O } 430.2 B \text { requires employment of integrated design principles } \\
\text { including protection and conservation of water, in accordance with the } \\
\text { HPSB Guiding Principles and the other building and construction- } \\
\text { related E.O. } 13423 \text { goals and instructions. } \\
\text { DOE O } 430.2 B \text { requires implementation of projects to conserve water } \\
\text { and procurement of water efficient products and services (such as } \\
\text { WaterSense labeled products or certified contractors). } \\
\text { EO } 13423 \text { sets goals for water efficiency and conservation. }\end{array}$ \\
\hline
\end{tabular}




\section{Y-12 Sustainable Design Principles for Building Design and Construction}

\begin{tabular}{|c|c|c|c|}
\hline $\begin{array}{l}\text { Sustainable } \\
\text { Building } \\
\text { Principle } \\
\text { (Required) }\end{array}$ & $\begin{array}{l}\text { Sustainable } \\
\text { Building } \\
\text { Practice(s) } \\
\text { (Required) }\end{array}$ & $\begin{array}{l}\text { Sustainable Building Techniques } \\
\text { (Refer to Section I of this document for resources) } \\
\text { *REQUIRED Techniques are shown in Bold font } \\
\text { Other /recommended techniques are shown in italics }\end{array}$ & Key Sustainable Building Drivers \\
\hline $\begin{array}{c}3 . \\
\text { Protect and } \\
\text { Conserve } \\
\text { Water }\end{array}$ & $\begin{array}{c}\text { 3.b } \\
\text { Outdoor- } \\
\text { Reduce outdoor } \\
\text { potable water } \\
\text { use by 50\% } \\
\text { over } \\
\text { conventional } \\
\text { means }\end{array}$ & 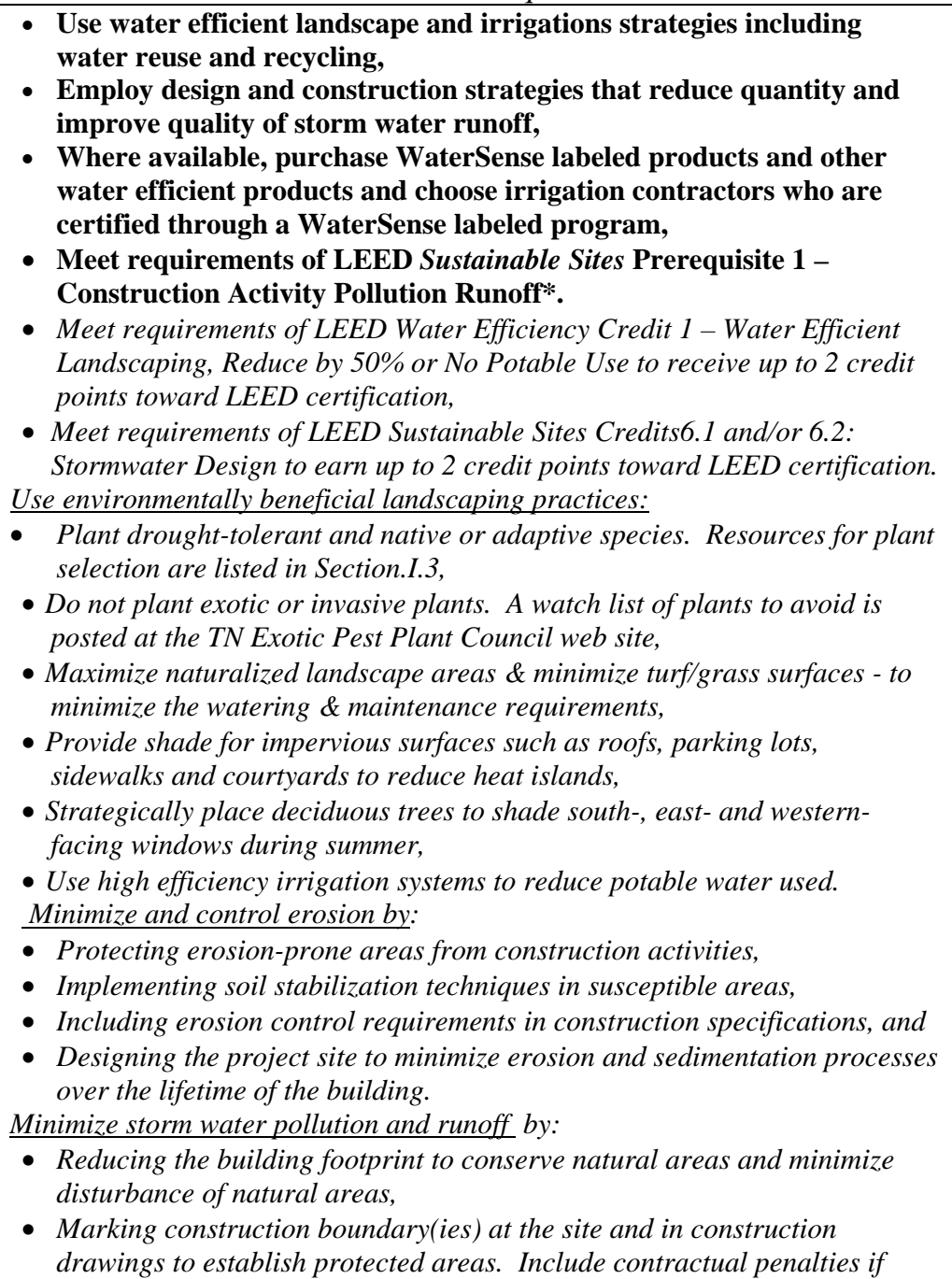 & $\begin{array}{l}\text { DOE O } 413.3 A \text { requires contractors to apply high performance } \\
\text { sustainable building (HPSB) principles to siting, design, construction } \\
\text { and commissioning of new facilities and major renovations. The HPSB } \\
\text { principles are given in the January } 2006 \text { HPSB MOU and are detailed in } \\
\text { DOE G 413.3-6 Attachment A. } \\
\text { DOE O 430.2B requires capital asset and major renovation projects to } \\
\text { attain LEED Gold certification for all new construction and major } \\
\text { building renovations in excess of } \$ 5 \text { million. All buildings falling below } \\
\text { this threshold are required to comply with the Guiding Principles for } \\
\text { Federal Leadership in High Performance and Sustainable Buildings } \\
\text { (HPSB principles). } \\
\text { DOE O } 430.2 B \text { requires Y-12 to conserve water in line with EO } 13423 \\
\text { goals and instructions; and employment of integrated design principles } \\
\text { including protection and conservation of water, in accordance with the } \\
\text { HPSB Guiding Principles and the other building and construction- } \\
\text { related E.O. } 13423 \text { goals and instructions. } \\
\text { EO } 13423 \text { sets goals for water efficiency and conservation. } \\
\text { Y-12 Storm Water Pollution Prevention Plan requires use of best } \\
\text { management practices to preserve and protect the water quality and } \\
\text { natural flow of storm water throughout the Y-12 Complex. The plan } \\
\text { focuses on reducing site runoff, minimizing soil erosion and silt } \\
\text { buildup, and minimizing outdoor storage of materials that could } \\
\text { negatively impact storm water quality. }\end{array}$ \\
\hline
\end{tabular}




\section{$\underline{\text { Y-12 Sustainable Design Principles for Building Design and Construction }}$}

\begin{tabular}{|c|c|c|c|}
\hline $\begin{array}{l}\text { Sustainable } \\
\text { Building } \\
\text { Principle } \\
\text { (Required) }\end{array}$ & $\begin{array}{l}\text { Sustainable } \\
\text { Building } \\
\text { Practice(s) } \\
\text { (Required) }\end{array}$ & $\begin{array}{l}\text { Sustainable Building Techniques } \\
\text { (Refer to Section I of this document for resources) } \\
\text { *REQUIRED Techniques are shown in Bold font } \\
\text { Other /recommended techniques are shown in italics }\end{array}$ & Key Sustainable Building Drivers \\
\hline & & $\begin{array}{l}\text { destruction of protected areas occurs, } \\
\text { - Constructing biologically based storm water management features to filter } \\
\text { and purify storm water, } \\
\text { - Constructing vegetative buffers around parking areas to capture runoff } \\
\text { and remove pollutants such as oil, } \\
\text { - Installing rainwater / storm water collection system(s) to harvest storm } \\
\text { water for non -potable uses, } \\
\text { - Reducing impervious paving surfaces by using porous (pervious) paving to } \\
\text { increase water recharge rates, } \\
\text { - Utilizing vegetative or 'green' roof surfaces. }\end{array}$ & \\
\hline $\begin{array}{c}4 . \\
\text { Enhance } \\
\text { Indoor } \\
\text { Environmental } \\
\text { Quality }\end{array}$ & $\begin{array}{l}\text { 4.a } \\
\text { Use low- } \\
\text { emitting } \\
\text { materials }\end{array}$ & $\begin{array}{l}\text { Specify materials and products with low pollutant emissions, including } \\
\text { adhesives, sealants, paints, carpet systems, and furnishings. } \\
\text { - Meet requirements of LEED Indoor Environmental Quality Credits } 4.1 \text { - } \\
\text { 4.4: Low-Emitting Materials to receive up to } 4 \text { credit points toward LEED } \\
\text { certification. } \\
\text { Utilize low-emitting materials such as: } \\
\text { - Low-volatile organic content (VOC) paints, coatings, adhesives, and } \\
\text { sealants, } \\
\text { - Low-emitting carpet systems with high recycled content, } \\
\text { - Composite wood, bamboo, and agri-fiber products with no added urea- } \\
\text { - Cormaldehyde resins, } \\
\text { envining products certified by GreenSeal, a U.S. standard setting and } \\
\text { designated green cleaning products } \\
\text { - } \text { - } \text { Gww.epa.gov/opptintr/epp/cleaners/select), } \\
\text { system. A list of these products is posted on the Y-12 Pollution Prevention } \\
\text { website, } \\
\text { - Specify use of green cleaning products during final building } \\
\text { commissioning. }\end{array}$ & $\begin{array}{l}\text { DOE O 413.3A requires contractors to apply high performance } \\
\text { sustainable building (HPSB) principles to siting, design, construction } \\
\text { and commissioning of new facilities and major renovations. The HPSB } \\
\text { principles are given in the January } 2006 \text { HPSB MOU and are detailed in } \\
D O E \text { G } 413.3-6 \text { Attachment A. } \\
\text { DOE O 430.2B requires capital asset and major renovation projects to } \\
\text { attain LEED Gold certification for all new construction and major } \\
\text { building renovations in excess of } \$ 5 \text { million. All buildings falling below } \\
\text { this threshold are required to comply with the HPSB principles. } \\
\text { DOE O } 430.2 B \text { requires employment of integrated design principles } \\
\text { including enhancement of indoor environmental quality, and reduction } \\
\text { of environmental impacts of materials in accordance with the HPSB } \\
\text { Guiding Principles and the other building and construction-related E.O. } \\
13423 \text { goals and instructions. } \\
\text { DOE O } 450.1 A \text { requires Y-12 to reduce release of pollutants to the } \\
\text { environment, to maximize procurement of environmentally preferable } \\
\text { products, and to establish goals to reduce toxic chemical use and } \\
\text { release, maximize environmentally-preferable product purchases and } \\
\text { report accomplishments to DOE. } \\
\text { EO } 13423 \text { requires contractors to require plans and specifications to } \\
\text { include use of bio-based, recovered materials, toxicity reduction, and } \\
\text { environmentally preferable products. }\end{array}$ \\
\hline
\end{tabular}




\section{Y-12 Sustainable Design Principles for Building Design and Construction}

\begin{tabular}{|c|c|c|c|}
\hline $\begin{array}{l}\text { Sustainable } \\
\text { Building } \\
\text { Principle } \\
\text { (Required) }\end{array}$ & $\begin{array}{l}\text { Sustainable } \\
\text { Building } \\
\text { Practice(s) } \\
\text { (Required) } \\
\end{array}$ & $\begin{array}{l}\text { Sustainable Building Techniques } \\
\text { (Refer to Section I of this document for resources) } \\
\text { *REQUIRED Techniques are shown in Bold font } \\
\text { Other /recommended techniques are shown in italics }\end{array}$ & Key Sustainable Building Drivers \\
\hline $\begin{array}{l}4 . \\
\text { Enhance Indoor } \\
\text { Environmental } \\
\text { Quality }\end{array}$ & $\begin{array}{l}\text { 4.b } \\
\text { Optimize } \\
\text { ventilation and } \\
\text { thermal } \\
\text { comfort. }\end{array}$ & $\begin{array}{l}\text { - Meet the current ASHRAE Standard 55-2004 (including continuous } \\
\text { humidity control within established ranges per climate zone) and } \\
\text { ASHRAE Standard 62.1-2004 Ventilation for Acceptable Indoor Air } \\
\text { Quality. } \\
\text { - Meet requirements of LEED Indoor Environmental Quality } \\
\text { Prerequisite 1: Minimum IAQ Performance; and Prerequisite 2: } \\
\text { Environmental Tobacco Smoke*. } \\
\text { - Meet requirements of LEED Indoor Environmental Quality Credit } \\
\text { 1:Outdoor Air Delivery Monitoring, Credit 2: Increased Ventilation, } \\
\text { and/or Credit 5: Indoor Chemical \& Pollutant Source Control to receive } \\
\text { up to } 3 \text { credit points toward LEED certification, } \\
\text { - Meet requirements of LEED Indoor Environmental Quality Credit 6.2: } \\
\text { Controllability of Systems, Thermal Comfort to receive up to one credit } \\
\text { point toward LEED certification, } \\
\text { - Meet requirements of LEED Indoor Environmental Quality Credit 7. \& } \\
\text { 7.2: Thermal Comfort Design \& Verification to receive up to } 2 \text { credit } \\
\text { points toward LEED certification, } \\
\text { - Install indoor air quality monitoring (e.g.,CO }{ }_{2} \text { ), } \\
\text { - Provide thermal comfort with a maximum degree of personal control over } \\
\text { temperature and humidity, } \\
\text { - Supply adequate levels of ventilation and outside air to ensure indoor air } \\
\text { quality, } \\
\text { - Assure acoustic privacy and comfort through the use of sound absorbing } \\
\text { material and equipment isolation, } \\
\text { - Control odors through contaminant isolation and use of low VOC cleaning } \\
\text { products. }\end{array}$ & $\begin{array}{l}\text { DOE O 413.3A requires contractors to apply high performance } \\
\text { sustainable building (HPSB) principles to siting, design, construction } \\
\text { and commissioning of new facilities and major renovations. The HPSB } \\
\text { principles are given in the January } 2006 \text { HPSB MOU and are detailed in } \\
D O E \text { G 413.3-6 Attachment A. } \\
\text { DOE O 430.2B requires capital asset and major renovation projects to } \\
\text { attain LEED Gold certification for all new construction and major } \\
\text { building renovations in excess of } \$ 5 \text { million. All buildings falling below } \\
\text { this threshold are required to comply with the Guiding Principles for } \\
\text { Federal Leadership in High Performance and Sustainable Buildings } \\
\text { (HPSB principles). } \\
\text { DOE O 430.2B requires employment of integrated design principles } \\
\text { including enhancement of indoor environmental quality, and reduction } \\
\text { of environmental impacts of materials in accordance with the HPSB } \\
\text { Guiding Principles and the other building and construction-related E.O. } \\
13423 \text { goals and instructions. }\end{array}$ \\
\hline $\begin{array}{l}\text { 4. } \\
\text { Enhance Indoor } \\
\text { Environmental } \\
\text { Quality }\end{array}$ & $\begin{array}{c}\text { 4.c } \\
\text { Control } \\
\text { moisture. }\end{array}$ & $\begin{array}{l}\text { - Establish and implement a moisture control strategy for controlling } \\
\text { moisture flows and condensation to prevent building damage and } \\
\text { mold contamination, } \\
\text { - Meet requirements of LEED Energy and Atmosphere Prerequisite 1: } \\
\text { Fundamental Commissioning of the Building Energy Systems*. }\end{array}$ & $\begin{array}{l}\text { DOE O 413.3A requires contractors to apply high performance } \\
\text { sustainable building (HPSB) principles to siting, design, construction } \\
\text { and commissioning of new facilities and major renovations. The HPSB } \\
\text { principles are given in the January } 2006 \mathrm{HPSB} M O U \text { and are detailed in } \\
D O E G \text { 413.3-6 Attachment A. } \\
\text { DOE O 430.2B requires capital asset and major renovation projects to } \\
\text { attain LEED Gold certification for all new construction and major } \\
\text { building renovations in excess of } \$ 5 \text { million. All buildings falling below } \\
\text { this threshold are required to comply with the High Performance and } \\
\text { Sustainable Buildings (HPSB) principles. }\end{array}$ \\
\hline
\end{tabular}




\section{Y-12 Sustainable Design Principles for Building Design and Construction}

\begin{tabular}{|c|c|c|c|}
\hline $\begin{array}{l}\text { Sustainable } \\
\text { Building } \\
\text { Principle } \\
\text { (Required) }\end{array}$ & $\begin{array}{l}\text { Sustainable } \\
\text { Building } \\
\text { Practice(s) } \\
\text { (Required) }\end{array}$ & $\begin{array}{l}\text { Sustainable Building Techniques } \\
\text { (Refer to Section I of this document for resources) } \\
\text { *REQUIRED Techniques are shown in Bold font } \\
\text { Other /recommended techniques are shown in italics }\end{array}$ & Key Sustainable Building Drivers \\
\hline $\begin{array}{c}4 . \\
\text { Improve Indoor } \\
\text { Environmental } \\
\text { Quality }\end{array}$ & $\begin{array}{l}\text { 4.d } \\
\text { Maximize } \\
\text { daylighting. }\end{array}$ & $\begin{array}{l}\text { - Achieve a minimum daylight factor of } 2 \% \text { (excluding all direct sunlight } \\
\text { penetration) in } 75 \% \text { of all space occupied for critical visual tasks, } \\
\text { - Provide automatic dimming controls or accessible manual lighting } \\
\text { controls and appropriate glare control. } \\
\text { - Meet requirements of LEED Indoor Environmental Quality Credit 6.1: } \\
\text { Controllability of Systems, Lighting to receive up to one credit point toward } \\
\text { LEED certification, } \\
\text { - Meet requirements of LEED Indoor Environmental Quality Credits } 8.1 \text { - } \\
\text { 8.2: Daylight \& Views to receive up to } 2 \text { credit points toward LEED } \\
\text { certification, } \\
\text { - Integrate natural and artificial light sources, } \\
\text { - Value aesthetic decisions, such as the importance of views and integration } \\
\text { of natural and man-made elements. }\end{array}$ & $\begin{array}{l}\text { DOE O 413.3A requires contractors to apply high performance } \\
\text { sustainable building (HPSB) principles to siting, design, construction } \\
\text { and commissioning of new facilities and major renovations. The HPSB } \\
\text { principles are given in the January } 2006 \text { HPSB MOU and are detailed in } \\
\text { DOE G 413.3-6 Attachment A. } \\
\text { DOE O 430.2B requires capital asset and major renovation projects to } \\
\text { attain LEED Gold certification for all new construction and major } \\
\text { building renovations in excess of } \$ 5 \text { million. All buildings falling below } \\
\text { this threshold are required to comply with the Guiding Principles for } \\
\text { Federal Leadership in High Performance and Sustainable Buildings } \\
\text { (HPSB principles). }\end{array}$ \\
\hline $\begin{array}{c}4 . \\
\text { Enhance Indoor } \\
\text { Environmental } \\
\text { Quality }\end{array}$ & $\begin{array}{c}\text { 4.e } \\
\text { Protect indoor } \\
\text { air quality } \\
\text { during } \\
\text { construction. }\end{array}$ & $\begin{array}{l}\text { - Follow recommended approach of the Sheet Metal and Air } \\
\text { Conditioning Contractors National Association Indoor Air Quality } \\
\text { Guidelines for Occupied Buildings Under Construction 1995, } \\
\text { - After construction and prior to occupancy, conduct a minimum 72- } \\
\text { hour flush-out with maximum outdoor air consistent with achieving } \\
\text { relative humidity no greater than } 60 \% \text {, } \\
\text { - After occupancy, continue flush out as necessary to minimize exposure } \\
\text { to contaminants from new building materials. } \\
\text { - Meet requirements of LEED Indoor Environmental Quality Credit } 3.1 \\
\text { \&/or 3.2: Construction Indoor Air Quality Management Plan, During } \\
\text { Construction / Before Occupancy to receive up to } 2 \text { credit points toward } \\
\text { - LEED certification, } \\
\text { - Develop a construction Indoor Air Quality plan, } \\
\text { - Use protective filters on ductwork and replace filters prior to occupancy. }\end{array}$ & $\begin{array}{l}\text { DOE O 413.3A requires contractors to apply high performance } \\
\text { sustainable building (HPSB) principles to siting, design, construction } \\
\text { and commissioning of new facilities and major renovations. The HPSB } \\
\text { principles are given in the January } 2006 \mathrm{HPSB} M O U \text { and are detailed in } \\
\text { DOE G 413.3-6 Attachment A. } \\
\text { DOE O 430.2B requires capital asset and major renovation projects to } \\
\text { attain LEED Gold certification for all new construction and major } \\
\text { building renovations in excess of } \$ 5 \text { million. All buildings falling below } \\
\text { this threshold are required to comply with the Guiding Principles for } \\
\text { Federal Leadership in High Performance and Sustainable Buildings } \\
\text { (HPSB principles). } \\
\text { DOE O 430.2B requires employment of integrated design principles } \\
\text { including enhancement of indoor environmental quality, and reduction } \\
\text { of environmental impacts of materials in accordance with the HPSB } \\
\text { Guiding Principles and the other building and construction-related E.O. } \\
13423 \text { goals and instructions. }\end{array}$ \\
\hline
\end{tabular}




\section{$\underline{\text { Y-12 Sustainable Design Principles for Building Design and Construction }}$}

\begin{tabular}{|c|c|c|c|}
\hline $\begin{array}{l}\text { Sustainable } \\
\text { Building } \\
\text { Principle } \\
\text { (Required) }\end{array}$ & $\begin{array}{l}\text { Sustainable } \\
\text { Building } \\
\text { Practice(s) } \\
\text { (Required) }\end{array}$ & $\begin{array}{l}\text { Sustainable Building Techniques } \\
\text { (Refer to Section I of this document for resources) } \\
\text { *REQUIRED Techniques are shown in Bold font } \\
\text { Other /recommended techniques are shown in italics }\end{array}$ & Key Sustainable Building Drivers \\
\hline $\begin{array}{c}5 . \\
\text { Reduce } \\
\text { Environmental } \\
\text { Impact of } \\
\text { Materials }\end{array}$ & $\begin{array}{c}\text { 5.a.1 } \\
\text { Waste } \\
\text { Reduction - } \\
\text { Reduce waste } \\
\text { generated by } \\
\text { building } \\
\text { occupants. }\end{array}$ & $\begin{array}{l}\text { - Design buildings that provide space and access to accommodate Y-12 } \\
\text { recycling program activities, } \\
\text { - Meet requirements of LEED Materials \& Resources Prerequisite 1: } \\
\text { Storage \& Collection of Recyclables*. } \\
\text { Include in building designs: } \\
\text { - Well-marked recycling collection points on each floor, } \\
\text { - Space for recycling throughout offices and lunch/breakrooms, } \\
\text { - Ground floor storage area for recyclables, sheltered from weather, } \\
\text { supplied with electric utilities and lighting, and accessible by large } \\
\text { trucks, } \\
\text { - Passageways sized to allow transport of recyclables from collection } \\
\text { points to ground floor storage area(s), } \\
\text { - Utilities and space in the storage area to allow for a cardboard } \\
\text { compactor, can crusher (as appropriate), and storage of cooking grease } \\
\text { and food waste (if facility includes cafeteria), } \\
\text { - Cafeterias designed to allow for segregated collection of steel and } \\
\text { aluminum cans, a can crusher, and equipment associated with } \\
\text { collection of cooking grease and food waste. }\end{array}$ & $\begin{array}{l}D O E O \text { 430.2B requires capital asset and major renovation projects to } \\
\text { attain LEED Gold certification for all new construction and major } \\
\text { building renovations in excess of } \$ 5 \text { million. All buildings falling below } \\
\text { this threshold are required to comply with the Guiding Principles for } \\
\text { Federal Leadership in High Performance and Sustainable Buildings } \\
\text { (HPSB principles). } \\
\text { DOE } O 430.2 B \text { requires employment of integrated design principles } \\
\text { including reduction of environmental impacts of materials in accordance } \\
\text { with the HPSB Guiding Principles and the other building and } \\
\text { construction-related E.O. } 13423 \text { goals and instructions. } \\
\text { DOE } O 450.1 A \text { requires reduced waste generation, and release of } \\
\text { pollutants to the environment, establishment of a recycling goal and } \\
\text { reporting recycled quantities to DOE. } \\
\text { EO } 13423 \text { mandates federal contractors to initiate programs to promote } \\
\text { cost-effective waste reduction } \\
\text { and recycling. requires recycling programs to include various types of } \\
\text { waste, and requires a program to promote cost-effective recycling in all } \\
\text { facilities. } \\
Y 77-177, Y \text {-12 Complex-Wide Recycling establishes recycling } \\
\text { requirements to satisfy the above drivers, and requires several waste } \\
\text { streams to be recycled. }\end{array}$ \\
\hline
\end{tabular}




\section{Y-12 Sustainable Design Principles for Building Design and Construction}

\begin{tabular}{|c|c|c|c|}
\hline $\begin{array}{l}\text { Sustainable } \\
\text { Building } \\
\text { Principle } \\
\text { (Required) }\end{array}$ & $\begin{array}{l}\text { Sustainable } \\
\text { Building } \\
\text { Practice(s) } \\
\text { (Required) }\end{array}$ & $\begin{array}{l}\text { Sustainable Building Techniques } \\
\text { (Refer to Section I of this document for resources) } \\
\text { *REQUIRED Techniques are shown in Bold font } \\
\text { Other /recommended techniques are shown in italics }\end{array}$ & Key Sustainable Building Drivers \\
\hline $\begin{array}{c}5 . \\
\text { Reduce } \\
\text { Environmental } \\
\text { Impact of } \\
\text { Materials }\end{array}$ & $\begin{array}{c}\text { 5.a.2 } \\
\text { Waste } \\
\text { Reduction:- } \\
\text { Minimize } \\
\text { construction } \\
\text { waste }\end{array}$ & $\begin{array}{l}\text { - During project's planning stage, identify local recycling and salvage } \\
\text { operations that could process site related waste, } \\
\text { - Program the design to recycle or salvage at least } 50 \% \text { construction, } \\
\text { demolition and land clearing waste, excluding soil, where markets or } \\
\text { on-site recycling opportunities exist. } \\
\text { - Meet requirements of LEED Materials \& Resources Credit } 2.1 \text { or 2.2: } \\
\text { Construction Waste Management, Divert } 50 \% \text { or } 75 \% \text { from Disposal to } \\
\text { receive up to } 2 \text { credit points toward LEED certification, } \\
\text { - Incorporate recycling and waste minimization requirements into } \\
\text { - } \quad \text { Enconstruction subcontract language, } \\
\text { - } \quad \text { Provide a dedicated area for recycling, } \\
\text { - Develop a construction waste recycling plan, } \\
\text { - Reuse demolition rubble on-site for grading, laying utilities, roads and } \\
\text { parking areas. }\end{array}$ & $\begin{array}{l}\text { DOE O 413.3A requires contractors to apply high performance } \\
\text { sustainable building (HPSB) principles to siting, design, construction } \\
\text { and commissioning of new facilities and major renovations. The HPSB } \\
\text { principles are given in the January } 2006 \text { HPSB MOU and are detailed in } \\
\text { DOE G 413.3-6 Attachment A. } \\
\text { DOE O 430.2B requires capital asset and major renovation projects to } \\
\text { attain LEED Gold certification for all new construction and major } \\
\text { building renovations in excess of } \$ 5 \text { million. All buildings falling below } \\
\text { this threshold are required to comply with the Guiding Principles for } \\
\text { Federal Leadership in High Performance and Sustainable Buildings } \\
\text { (HPSB principles). } \\
\text { DOE O 450.1A includes a sustainable environmental stewardship goal } \\
\text { to maximize recycle and reuse of construction waste and debris. }\end{array}$ \\
\hline $\begin{array}{c}5 . \\
\text { Reduce } \\
\text { Environmental } \\
\text { Impact of } \\
\text { Materials }\end{array}$ & $\begin{array}{c}\text { 5.b } \\
\text { Maximize use } \\
\text { of materials } \\
\text { with Recycled } \\
\text { content } \\
\text { (designated in } \\
\text { the EPA } \\
\text { Comprehensive } \\
\text { Procurement } \\
\text { Guidelines } \\
\text { (CPG)) }\end{array}$ & $\begin{array}{l}\text { - For EPA-designated products, use products meeting or exceeding } \\
\text { EPA's recycled content recommendations, } \\
\text { - For other products, use materials with recycled content such that the } \\
\text { sum of post-consumer recycled content plus one-half of the pre- } \\
\text { consumer content constitutes at least } 10 \% \text { (based on cost) of the total } \\
\text { value of the materials in the project, } \\
\text { - Incorporate EPA-designated items in building design specifications } \\
\text { and material selection with recycled content that meets or exceeds the } \\
\text { CPG guidelines. Common construction items include: Insulation, } \\
\text { carpet; cement and concrete w/ fly-ash; latex paint (reprocessed); floor } \\
\text { tiles; patio blocks; shower and restroom dividers; fiberboard \& } \\
\text { laminated paperboard; non-pressure pipe; roofing materials; office } \\
\text { furniture; plastic fencing; parking stops; traffic barricades, } \\
\text { - During construction, ensure that the actual materials installed are } \\
\text { those that were specified in contract documents. } \\
\text { - Meet requirements of LEED Materials \& Resources Credit } 4.1 \text { or } 4.2 \text { : } \\
\text { Recycled Content, } 10 \% \text { or } 20 \% \text { to receive up to } 2 \text { credit points toward } \\
\text { LEED certification, } \\
\text { Encourage use of recyclable assemblies and products that can be easily de- } \\
\text { constructed at the end of their useful lives. } \\
\text { More Information on websites that list EPP sources are listed in Sec.I.5.b }\end{array}$ & $\begin{array}{l}\text { DOE O } 413.3 \text { A requires contractors to apply high performance } \\
\text { sustainable building (HPSB) principles to siting, design, construction } \\
\text { and commissioning of new facilities and major renovations. The HPSB } \\
\text { principles are given in the January } 2006 \text { HPSB MOU and are detailed in } \\
D O E G \text { 413.3-6 Attachment A. } \\
\text { DOE O 430.2B requires capital asset and major renovation projects to } \\
\text { attain LEED Gold certification for all new construction and major } \\
\text { building renovations in excess of } \$ 5 \text { million. All buildings falling below } \\
\text { this threshold are required to comply with the Guiding Principles for } \\
\text { Federal Leadership in High Performance and Sustainable Buildings } \\
\text { (HPSB principles). } \\
\text { DOE O } 450.1 A \text { requires contractors to reduce/eliminate pollutants by } \\
\text { buying recycled- and biobased-content materials, maximizing purchases } \\
\text { of environmentally preferable products; assisting DOE in meeting EO } \\
13423 \text { requirement; and requires Y-12 to establish a goal to maximize } \\
\text { purchases of recycled and bio-based content materials and to report } \\
\text { quantities to DOE. } \\
\text { EO } 13423 \text { requires contractors to give preference to use of bio-based, } \\
\text { recovered materials, toxicity reduction, and environmentally preferable }\end{array}$ \\
\hline
\end{tabular}




\section{Y-12 Sustainable Design Principles for Building Design and Construction}

\begin{tabular}{|c|c|c|c|}
\hline $\begin{array}{l}\text { Sustainable } \\
\text { Building } \\
\text { Principle } \\
\text { (Required) }\end{array}$ & $\begin{array}{l}\text { Sustainable } \\
\text { Building } \\
\text { Practice(s) } \\
\text { (Required) }\end{array}$ & $\begin{array}{l}\text { Sustainable Building Techniques } \\
\text { (Refer to Section I of this document for resources) } \\
\text { *REQUIRED Techniques are shown in Bold font } \\
\text { Other /recommended techniques are shown in italics }\end{array}$ & Key Sustainable Building Drivers \\
\hline & & & $\begin{array}{l}\text { products, and to evaluate contracts awards based on these factors. } \\
\text { Y77-938, Y-12 Environmentally Preferable Purchasing Instruction } \\
\text { makes Y-12 staff responsible to ensure all purchases meet } \\
\text { environmentally preferable purchasing requirements. }\end{array}$ \\
\hline $\begin{array}{l}5 . \\
\text { Reduce } \\
\text { Environmental } \\
\text { Impact of } \\
\text { Materials }\end{array}$ & $\begin{array}{l}\text { 5.c } \\
\text { Maximize use } \\
\text { of USDA- } \\
\text { designated bio- } \\
\text { based products. }\end{array}$ & $\begin{array}{l}\text { - For USDA-designated products, use products meeting or exceeding } \\
\text { USDA's biobased content recommendations, } \\
\text { - For other products, use biobased products made from rapidly } \\
\text { renewable resources and certified sustainable wood products, } \\
\text { - Incorporate USDA designated biobased products in building design } \\
\text { specifications, material selection, and contract documents. Table } 2 \\
\text { lists some of the common construction items that can be included, } \\
\text { - During construction, ensure that the actual materials installed are } \\
\text { those that were specified in contract documents. } \\
\text { - Meet requirements of LEED Materials \& Resources Credit 6: Rapidly } \\
\text { Renewable Materials and/or Credit 7: Certified Wood to receive up to } 2 \\
\text { points toward LEED certification, } \\
\text { - Use rapidly renewable / bio-based materials such as: bamboo flooring, } \\
\text { bio-based plastics (from cornstarch), wheatboard panels, wheatgrass } \\
\text { cabinetry, sunflower seed board, and cotton batt insulation. }\end{array}$ & $\begin{array}{l}\text { DOE O 413.3A requires contractors to apply high performance } \\
\text { sustainable building (HPSB) principles to siting, design, construction } \\
\text { and commissioning of new facilities and major renovations. The HPSB } \\
\text { principles are given in the January } 2006 \text { HPSB MOU and are detailed in } \\
D O E \text { G } 413.3-6 \text { Attachment A. } \\
\text { DOE O 430.2B requires capital asset and major renovation projects to } \\
\text { attain LEED Gold certification for all new construction and major } \\
\text { building renovations in excess of } \$ 5 \text { million. All buildings falling below } \\
\text { this threshold are required to comply with the Guiding Principles for } \\
\text { Federal Leadership in High Performance and Sustainable Buildings } \\
\text { (HPSB principles). } \\
\text { DOE O } 450.1 A \text { requires contractors to reduce/eliminate pollutants by } \\
\text { buying recycled- and biobased-content materials, maximizing purchases } \\
\text { of environmentally preferable products, assisting DOE in meeting EO } \\
13423 \text { requirements and requires establishment of a goal to maximize } \\
\text { purchases of recycled and bio-based content materials and to report } \\
\text { quantities to DOE. } \\
\text { EO } 13423 \text { requires contractors to give preference to use of bio-based, } \\
\text { recovered materials, toxicity reduction, and environmentally preferable } \\
\text { products, and to evaluate contracts awards based on these factors. } \\
Y 77-938, Y \text {-12 Environmentally Preferable Purchasing Instruction } \\
\text { makes Y-12 staff responsible to ensure all purchases meet } \\
\text { environmentally preferable purchasing requirements. }\end{array}$ \\
\hline
\end{tabular}




\section{$\underline{\text { Y-12 Sustainable Design Principles for Building Design and Construction }}$}

\begin{tabular}{|c|c|c|c|}
\hline $\begin{array}{l}\text { Sustainable } \\
\text { Building } \\
\text { Principle } \\
\text { (Required) }\end{array}$ & $\begin{array}{l}\text { Sustainable } \\
\text { Building } \\
\text { Practice(s) } \\
\text { (Required) }\end{array}$ & $\begin{array}{l}\text { Sustainable Building Techniques } \\
\text { (Refer to Section I of this document for resources) } \\
\text { *REQUIRED Techniques are shown in Bold font } \\
\text { Other /recommended techniques are shown in italics }\end{array}$ & Key Sustainable Building Drivers \\
\hline $\begin{array}{c}5 . \\
\text { Reduce } \\
\text { Environmental } \\
\text { Impact of } \\
\text { Materials }\end{array}$ & $\begin{array}{c}5 . d \\
\text { Eliminate use } \\
\text { of ozone } \\
\text { depleting } \\
\text { compounds } \\
\text { (ODC). }\end{array}$ &  & $\begin{array}{l}\text { DOE O 413.3A requires contractors to apply high performance } \\
\text { sustainable building (HPSB) principles to siting, design, construction } \\
\text { and commissioning of new facilities and major renovations. The HPSB } \\
\text { principles are given in the January } 2006 \text { HPSB MOU and are detailed in } \\
D O E \text { G 413.3-6 Attachment A. } \\
\text { DOE O 430.2B requires capital asset and major renovation projects to } \\
\text { attain LEED Gold certification for all new construction and major } \\
\text { building renovations in excess of } \$ 5 \text { million. All buildings falling below } \\
\text { this threshold are required to comply with the Guiding Principles for } \\
\text { Federal Leadership in High Performance and Sustainable Buildings } \\
\text { (HPSB principles). } \\
\text { DOE O } 450.1 A \text { requires elimination of the use of ODC, requires a } \\
\text { program to maximize use of safe alternatives to ODC, establishment of a } \\
\text { goal to reduce or eliminate toxic chemical releases (including ODC), } \\
\text { maximize environmentally preferable product use, and report results to } \\
\text { DOE } \\
\text { EO } 13423 \text { requires establishing goals to identify and reduce the release } \\
\text { and use of ozone-depleting substances (ODSs), and other pollutants that } \\
\text { may result in significant harm to human health or the environment. }\end{array}$ \\
\hline
\end{tabular}




\section{Y-12 Sustainable Design Principles for Building Design and Construction}

\begin{tabular}{|c|c|c|c|}
\hline $\begin{array}{l}\text { Sustainable } \\
\text { Building } \\
\text { Principle } \\
\text { (Required) }\end{array}$ & $\begin{array}{l}\text { Sustainable } \\
\text { Building } \\
\text { Practice(s) } \\
\text { (Required) } \\
\end{array}$ & $\begin{array}{l}\text { Sustainable Building Techniques } \\
\text { (Refer to Section I of this document for resources) } \\
\text { *REQUIRED Techniques are shown in Bold font } \\
\text { Other /recommended techniques are shown in italics }\end{array}$ & Key Sustainable Building Drivers \\
\hline $\begin{array}{c}5 . \\
\text { Reduce } \\
\text { Environmental } \\
\text { Impact of } \\
\text { Materials }\end{array}$ & $\begin{array}{c}\text { 5.e } \\
\text { Use materials } \\
\text { and equipment } \\
\text { with less } \\
\text { environmental } \\
\text { impact. }\end{array}$ & $\begin{array}{l}\text { - Meet requirements of LEED Materials \& Resources Credits } 3.1 \text { or } \\
\text { 3.1:Materials Reuse, 5\% or } 10 \% \text { to receive up to } 2 \text { points toward LEED } \\
\text { certification, } \\
\text { - Meet requirements of LEED Materials \& Resources Credits } 5.1 \text { or 5.1: } \\
\text { Regional Materials, } 10 \% \text { or } 20 \% \text { to receive up to } 2 \text { points toward LEED } \\
\text { certification, } \\
\text { - Use regional materials such as locally produced products and other } \\
\text { products with low embodied energy content. Use building materials and } \\
\text { resources that are regionally manufactured and/or incorporate as much } \\
\text { salvaged and recycled content as possible, } \\
\text { - Eliminate use of materials that pollute or are toxic during their } \\
\text { manufacture, use or reuse, } \\
\text { Include selected environmentally preferable products in design } \\
\text { specifications and contract documents. During construction, ensure that } \\
\text { the actual materials installed are those that were specified in contract } \\
\text { documents, } \\
\text { Also see techniques listed for improving indoor environmental quality } \\
\text { through use of low-emitting materials (Section 4). }\end{array}$ & $\begin{array}{l}\text { DOE O 413.3A requires contractors to apply high performance } \\
\text { sustainable building (HPSB) principles to siting, design, construction } \\
\text { and commissioning of new facilities and major renovations. The HPSB } \\
\text { principles are given in the January } 2006 \mathrm{HPSB} M O U \text { and are detailed in } \\
D O E G \text { 413.3-6 Attachment A. } \\
\text { DOE O 430.2B requires capital asset and major renovation projects to } \\
\text { attain LEED Gold certification for all new construction and major } \\
\text { building renovations in excess of } \$ 5 \text { million. All buildings falling below } \\
\text { this threshold are required to comply with the Guiding Principles for } \\
\text { Federal Leadership in High Performance and Sustainable Buildings } \\
\text { (HPSB principles). } \\
\text { DOE O } 450.1 A \text { requires government contractors to maximize } \\
\text { procurement of environmentally preferable products. } \\
\text { EO } 13423 \text { requires contractors to plan for and specify use of bio-based, } \\
\text { recovered materials, toxicity reduction, and environmentally preferable } \\
\text { products. }\end{array}$ \\
\hline
\end{tabular}

* LEED Prerequisites are required for construction projects and major facility renovations that are required to obtain LEED Gold certification under DOE O 430.2B (construction and renovations in excess of \$5 million). LEED certification is not required for smaller projects (under \$5 million), however incorporation of the sustainable building principle, practices and bolded techniques included in this table that are not marked by an asterisk are required. An exemption process for relieving the LEED Gold certification requirement that applies to larger projects is defined in DOE O 430.2B.

P2 = Pollution Prevention

DOE O = DOE Order

$\mathrm{CRD}=$ Contractor Requirements Document 


\section{Sustainable Building Principles, Practices and Techniques}

\section{Employ Integrated Design Principles}

1.a Sustainable Building Practice: Use a collaborative and integrated planning and design process.

\section{1.a Sustainable Building Technique(s):}

Required:

- Initiate and maintain an integrated project team in all stages of a project's planning and delivery,

- Establish performance goals for siting, energy, water, materials, and indoor environmental quality along with other comprehensive design goals,

- Ensure incorporation of above goals throughout the design and lifecycle of the building,

- Consider all stages of the building lifecycle, including deconstruction.

\section{Other / Recommended:}

- Use Leadership in Energy and Environmental Design (LEED) Accredited Professional to assist with the design process (receive one credit point toward LEED certification under LEED Innovation and Design Process Credit 2),

- For a list of LEED accredited professionals, see: http://www.usgbc.org/LEED/AP/ViewAll.aspx

1.b Sustainable Building Practice: Employ total building commissioning practices.

\section{1.b Sustainable Building Technique(s):}

Required:

- Tailor commissioning to size and complexity of the building and its system components in order to verify performance of building components and systems and help ensure that design requirements are met,

- Include a designated commissioning authority,

- Include commissioning requirements in construction documents,

- Develop a commissioning plan,

- Verify installation and performance of systems to be commissioned,

- Create a commissioning report, 


\section{$\underline{\text { Y-12 Sustainable Design Principles for Building Design and Construction }}$}

- Meet requirements of LEED Energy and Atmosphere Prerequisite 1: Fundamental Commissioning of Building Energy Systems.* see Table 1 footnote

Other / Recommended:

- Meet additional commissioning requirements of LEED Energy and Atmosphere Credit 3- Enhanced Commissioning to receive one point toward LEED certification.

\section{Optimize Energy Performance}

2.a Sustainable Building Practice: Optimize building energy efficiency

\section{2.a Sustainable Design Technique(s):}

Required:

- Establish whole building performance target that takes into account the intended use, occupancy, operations, plug loads, other energy demands, and design to earn the Energy Star targets for new construction and major renovation where applicable,

- For new construction, reduce the energy cost budget by $30 \%$ compared to the baseline building performance rating per the American Society of Heating, Refrigerating and Air-Conditioning Engineers (ASHRAE) and the Illuminating Engineering Society of North America (IESNA) Standard 90.1-2004,

- For major renovations, reduce the energy cost budget by $20 \%$ below prerenovations 2003 baseline,

- Meet requirements of LEED Energy and Atmosphere Prerequisite 2: Minimum Energy Performance,* see footnote Table 1

- Obtain at least 7 credit points under LEED Energy and Atmosphere Credit 1 - Optimize Energy Performance to meet 30\% energy reduction requirement, $*^{\text {see footnote Table } 1}$

- Incorporate the Y-12 Energy Savings Performance Contract (ESPC) efforts into building design and Y-12 modernization planning,

- Procure energy efficient products (Energy Star and products in upper 25 percent of energy efficiency, EPEAT and FEMP-designated).

\section{Other / Recommended:}

- Meet criteria for LEED Sustainable Sites Credits 7.1 and/or 7.2: Heat Island Effect to reduce heat loads of roof and non-roof surfaces, and receive up to 2 points toward LEED certification,

- Consider the design of the total building envelope and the energy conservation features incorporated into the building design in order to 'right-size' equipment (e.g., HVAC, lighting) to minimize their energy load,

- Utilize energy analysis software to evaluate energy efficiency alternatives. The preferred energy analysis software is DOE 2.2 (or Energy Plus) for PCs, 


\section{$\underline{\text { Y-12 Sustainable Design Principles for Building Design and Construction }}$}

- Use energy efficient window materials, insulation, and roofing (e.g., Energy Star compliant highly reflective and high emissivity roofing.),

- Use optimal day-lighting techniques to use natural lighting for building illumination during the day to reduce artificial lighting requirements,

- Use task lighting to reduce lighting requirements at night,

- Use energy efficient lighting technologies (e.g., fluorescent lighting, motion sensor lighting in bathrooms and conference rooms),

- Use passive solar techniques such as Trombe walls and proper building orientation to minimize heat load and reduce HVAC requirements,

- Design building to enable building-specific measurement and reporting of power and water consumption, and implementation of a customer- or building-specific charge program to curb unnecessary energy consumption and provide accurate usage information,

- Also see techniques listed for environmentally beneficial landscaping in Section 3.

\section{Resources:}

- DOE Environmentally Preferable Products handbook, http://www.hss.energy.gov/pp/epp/EPP-DOE-Handbook-rev12.pdf provides links to listings and web-sites for recycled and bio-based products, as well as water efficient and energy efficient products,

- Also refer to the resources listed on Page 4 of this document.

2.b Sustainable Building Practice: Enhance use of renewable energy sources.

\section{2.b Sustainable Building Technique(s):}

\section{Required:}

Reduce building use of petroleum-based fuels and utilize renewable energy where feasible and cost effective.

\section{Other / Recommended:}

- Meet requirements of LEED Energy and Atmosphere Credit 2: On-site Renewable Energy, and/or Credit 6: Green Power to earn up to 4 credit points toward LEED certification,

- Use natural gas instead of petroleum-based heating oils and fuels,

- Purchase grid-source non-hydroelectric renewable energy 'green power' (wind, solar, geothermal, and biomass technologies) such as the TVA Green Power program,

- Purchase electricity from less polluting generating plants such as new advanced-technology fossil energy systems and other highly efficient generating technologies where available,

- Incorporate off-grid generation systems such as solar hot water, solar electric, solar outdoor lighting, small wind turbines, fuel cells, and building-integrated photovoltaics (BIPV) into building design. 


\section{$\underline{\text { Y-12 Sustainable Design Principles for Building Design and Construction }}$}

Design buildings and parking structures to facilitate and promote a reduction in the amount of petroleum-based energy required to move personnel to and from Y-12, and within the Y-12 Complex. Potential sustainable design techniques include:

- Meet requirements of LEED Sustainable Sites Credits 4.1 - 4.4: Alternative Transportation to earn up to 4 credit points toward LEED certification,

- Plan for preferred parking spaces for employee carpools and for vehicles powered by alternative-fuels,

- Provide on-site access to alternative fuels (E-85 or bio-diesel) for Y-12 employees and the $\mathrm{Y}-12$ vehicle fleet,

- Provide inviting / sheltered seating area(s) for Y-12 shuttle users,

- Provide secure bicycle storage areas and convenient changing/shower facilities to provide employees with the opportunity to bike to work instead of drive,

- Provide bike racks within the Y-12 Complex.

2.c Sustainable Building Practice: Measure and verify energy consumption

\section{2.c Sustainable Building Technique(s):}

Required:

- Install building level utility meters in new major construction and renovation projects to track and continuously optimize performance (in accordance with DOE guidelines issued under section 103 of the Energy Policy Act of 2005),

- Compare actual performance data from the first year of operation with the energy design target,

- After one year of occupancy, measure all new major installations using the Energy Star benchmarking Tool for the building and space types covered by Energy Star,

- Enter data and lessons learned from sustainable buildings into the DOE High Performance Buildings Database.

Other/Recommended;

- Meet requirements of LEED Energy and Atmosphere Credit 5 - Measurement \& Verification to achieve one credit point toward LEED certification.

\section{Protect and Conserve Water}

3.a Sustainable Building Practice: Indoor - Reduce indoor water use 20\%.

\section{3.a Sustainable Building Technique(s):}

\section{Required:}

Employ strategies that in aggregate use a minimum of $20 \%$ less potable water than baseline calculated for the building after meeting EPAct of 1992 fixture performance requirements. 


\section{$\underline{\text { Y-12 Sustainable Design Principles for Building Design and Construction }}$}

\section{Other/Recommended:}

Meet requirements of LEED Water Efficiency Credit 3.1 or 3.2: Water Use Reduction $20 \%$ or $30 \%$ to receive up to 2 credit points toward LEED certification.

Design techniques include:

- Low flow or dual-flush toilets,

- Low flow showers,

- Auto-cutoff sinks,

- Dry fixtures such as waterless urinals and composting toilets,

- Plumbing fixtures that exceed the requirements of the Energy Policy Act,

- Water-efficient cooling towers that use delimiters to reduce drift and evaporation. (Note: there may be an energy trade-off due to potential need for larger fans on the delimiters),

- The DOE Environmentally Preferable Products handbook, http://www.hss.energy.gov/pp/epp/EPP-DOE-Handbook-rev12.pdf provides links to listings and web-sites for recycled and bio-based products, as well as water efficient and energy efficient products.

3.b Sustainable Building Practice: Outdoor - Reduce outdoor potable water use by $50 \%$ over conventional means.

\section{3.b Sustainable Building Technique(s):}

\section{Required:}

- Use water efficient landscape and irrigations strategies including water reuse and recycling,

- Employ design and construction strategies that reduce quantity and improve quality of storm water runoff,

- Meet requirements of LEED Sustainable Sites Prerequisite 1: Construction Activity Pollution Runoff.* see footnote Table 1

Other / Recommended:

- Meet requirements of LEED Water Efficiency Credit 1: Water Efficient Landscaping, Reduce by $50 \%$ or No Potable Use to receive up to 2 credits toward LEED certification.

Incorporate environmentally and economically beneficial landscaping to reduce water needs, pesticide use, maintenance requirements (mowing) and heat islands from impervious surfaces:

- Plant drought-tolerant and native or adaptive species (refer to plant lists available from the resources listed below),

- Do not plant exotic or invasive plant species as defined by the Tennessee Exotic Pest Plant Council. A watch list of plants to avoid is posted at www.tneppc.org, 


\section{$\underline{\text { Y-12 Sustainable Design Principles for Building Design and Construction }}$}

- Maximize naturalized landscape areas to minimize the watering, pesticide use and gas-powered maintenance associated with grass and turf surfaces,

- Provide shade for impervious surfaces such as parking lots, sidewalks and courtyards to reduce heat islands and lower building heat loads,

- Strategically place deciduous trees to shade south-, east- and western-facing windows during summer months to reduce building heat loads,

- Use high efficiency irrigation systems to reduce potable water used for irrigation.

Minimize and control erosion by:

- Protecting erosion-prone areas from construction activities,

- Implementing soil stabilization techniques in susceptible areas (e.g., seeding, mulching, earth dikes, sediment traps and basins),

- Including erosion control requirements in construction specifications, and

- Designing the project site to minimize erosion and sedimentation processes over the lifetime of the building.

Minimize storm water pollution and runoff, and increase on-site infiltration by:

- Reducing the building footprint to conserve natural areas and minimize disturbance of natural areas,

- Marking construction boundary(ies) at the site and in construction drawings to establish protected areas and construction and disturbance boundaries. Include contractual penalties if destruction of protected areas occurs,

- Constructing biologically based storm water management features such as constructed wetlands, bio-swales, and vegetated filter strips to filter and purify storm water before entry into surface streams,

- Constructing vegetative buffers around parking areas and water quality structures to capture parking area runoff and remove pollutants such as oil,

- Installing rainwater / storm water collection system(s) to harvest storm water from roofs and hardscapes to supply landscape irrigation and other nonpotable uses (e.g., sewage conveyance),

- $\quad$ Reducing impervious paving surfaces by using porous (pervious) paving technologies to increase water recharge rates,

- Utilizing vegetative or 'green' roof surfaces.

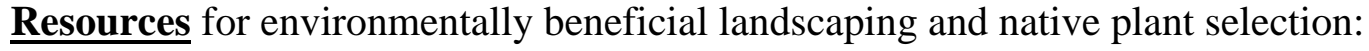

- Tennessee Valley Authority Native Plan Selector, www.tva.gov/river/landandshore/stabilization/plantsearch.htm. This site is a searchable list of more than 140 plants native to the Tennessee Valley and includes photographs and details about height, light preference and more,

- ORNL Conceptual Landscape Plan \& Design Guidelines, available at the internal Y-12 Pollution Prevention Program (Sustainability and Stewardship Program) website. The guide contains a native plant list and includes environmentally beneficial landscape techniques for sustainable design. 


\section{$\underline{\text { Y-12 Sustainable Design Principles for Building Design and Construction }}$}

\section{Enhance Indoor Environmental Quality}

4.a Sustainable Building Practice: Use low-emitting materials.

4.a Sustainable Building Technique(s):

Required:

Specify materials and products with low pollutant emissions, including adhesives, sealants, paints, carpet systems, and furnishings.

Other / Recommended:

Meet requirements of LEED Indoor Environmental Quality Credits 4.1 - 4.4:

Low-Emitting Materials to receive up to 4 credit points toward LEED certification.

Utilize low-emitting materials such as:

- Low-volatile organic content (VOC) paints, coatings, adhesives, and sealants,

- Low-emitting carpet systems with high recycled content,

- Composite wood, bamboo, and agri-fiber products with no added ureaformaldehyde resins,

- Cleaning products certified by GreenSeal, a U.S. standard setting and environmental labeling organizations (www.greenseal.org), and/or EPAdesignated green cleaning products (http://www.epa.gov/epp/index.htm),

- Green cleaning products available through the Y-12 AVID purchasing system. A list of these products is posted on the Y-12 Pollution Prevention (Sustainability and Environmental Stewardship) website,

- Specify use of green cleaning products during final building commissioning.

4.b Sustainable Building Practice: Optimize ventilation and thermal comfort.

\section{4.b Sustainable Building Technique(s):}

Required:

- Meet the current ASHRAE Standard 55-2004 (including continuous humidity control within established ranges per climate zone) and ASHRAE Standard 62.1-2004 Ventilation for Acceptable Indoor Air Quality,

- Meet requirements of LEED Indoor Environmental Quality Prerequisite 1: Minimum IAQ Performance; and Prerequisite 2: Environmental Tobacco Smoke.* See footnote Table 1

Other / Recommended:

- Meet requirements of LEED Indoor Environmental Quality Credit 1:Outdoor Air Delivery Monitoring, Credit 2: Increased Ventilation, and/or Credit 5: 


\section{$\underline{\text { Y-12 Sustainable Design Principles for Building Design and Construction }}$}

Indoor Chemical \& Pollutant Source Control to receive up to 3 credit points toward LEED certification,

- Meet requirements of LEED Indoor Environmental Quality Credit 6.2:

Controllability of Systems, Thermal Comfort to receive up to one credit point toward LEED certification,

- Meet requirements of LEED Indoor Environmental Quality Credit 7. \& 7.2:

Thermal Comfort Design \& Verification to receive up to 2 credit points toward LEED certification,

- Install indoor air quality monitoring (e.g., $\mathrm{CO}_{2}$ ),

- Provide thermal comfort with a maximum degree of personal control over temperature and humidity,

- Supply adequate levels of ventilation and outside air to ensure indoor air quality,

- Assure acoustic privacy and comfort through the use of sound absorbing material and equipment isolation,

- Control odors through contaminant isolation and use of low VOC cleaning products.

4.c Sustainable Building Practice: Control moisture.

\section{4.c Sustainable Building Technique(s):}

Required:

- Establish and implement a moisture control strategy for controlling moisture flows and condensation to prevent building damage and mold contamination,

- Meet requirements of LEED Energy and Atmosphere Prerequisite 1: Fundamental Commissioning of the Building Energy Systems. ${ }^{\text {see footnote }}$
Table 1

4.d Sustainable Building Practice: Maximize daylighting

4.d Sustainable Building Technique(s):

Required:

- Achieve a minimum daylight factor of $2 \%$ (excluding all direct sunlight penetration) in $75 \%$ of all space occupied for critical visual tasks,

- Provide automatic dimming controls or accessible manual lighting controls and appropriate glare control. 


\section{$\underline{\text { Y-12 Sustainable Design Principles for Building Design and Construction }}$}

Other/Recommended:

- Meet requirements of LEED Indoor Environmental Quality Credit 6.1:

Controllability of Systems, Lighting to receive up to one credit point toward LEED certification,

- Meet requirements of LEED Indoor Environmental Quality Credits 8.1 - 8.2: Daylight \& Views to receive up to 2 credit points toward LEED certification,

- Integrate natural and artificial light sources,

- Value aesthetic decisions, such as the importance of views and integration of natural and man-made elements.

4.e Sustainable Building Practice: Protect indoor air quality during construction

\section{4.e Sustainable Building Technique(s):}

Required:

- Follow recommended approach of the Sheet Metal and Air Conditioning Contractors National Association Indoor Air Quality Guidelines for Occupied Buildings under Construction 1995,

- After construction and prior to occupancy, conduct a minimum 72-hour flush-out with maximum outdoor air consistent with achieving relative humidity no greater than $60 \%$,

- After occupancy, continue flush out as necessary to minimize exposure to contaminants from new building materials.

Other / Recommended:

- Meet requirements of LEED Indoor Environmental Quality Credit 3.1 and/or 3.2: Construction Indoor Air Quality Management Plan, During Construction and/or Before Occupancy to receive up to 2 credit points toward LEED certification,

- Develop a construction Indoor Air Quality plan,

- Keep ductwork clean during construction,

- Protect ductwork with filters and replace filters prior to occupancy. 


\section{$\underline{\text { Y-12 Sustainable Design Principles for Building Design and Construction }}$}

\section{Reduce Environmental Impact of Materials}

5.a.1 Sustainable Building Practice: Waste Reduction - Reduce waste generated by building occupants.

Note:

- The amount of solid waste generated in office buildings ranges from 1- $1.5 \mathrm{lb}$ per 100 square feet per day,

- One office worker generates an average 2.9 pounds of waste per day. Approximately $80 \%$ of this office waste can be recycled,

- Recycling one ton of paper prevents the processing of 17 trees and saves three cubic yards of landfill space,

- Recycled aluminum requires only 5\% of the energy required to produce virgin aluminum from bauxite, its raw material.

\section{5.a.1 Sustainable Building Technique(s):}

Required:

- Meet requirements of LEED Materials \& Resources Prerequisite 1: Storage \& Collection of Recyclables, * see footnote Table 1

- Design buildings that provide space and access to accommodate Y-12 recycling program activities,

- Designate well-marked collection and storage areas for recyclables including office paper, newspaper, cardboard, glass, metals and plastic,

- Locate recycling collection points adjacent to work areas and lunch rooms on each building level,

- Allocate adequate space for recycling receptacles at collection points in office areas and lunchrooms,

- Locate a central collection/storage are in the basement or ground floor within easy access to collection points. The collection/storage area should provide adequate space to segregate and consolidate recycled materials to prepare and store them for pick-up by the Y-12 Recycling Program and other recycling vendors. The collection/storage space should be sheltered from weather, and supplied with electric utilities and lighting. The area should be located to allow access by large trucks,

- Design elevators, recycling chutes or other means of easy transport of materials to the ground floor staging/storage area. Passageways (e.g., hallways and door openings) should be designed to allow unencumbered transport of recycling bins from collection points to the ground floor recycled material staging/storage area,

- Include utilities and space in the staging/storage area to allow for a cardboard compactor/box baler, can crusher/compactor equipment (for large facilities), and storage of cooking grease and food waste to be recycled (if facility includes a cafeteria), 


\section{$\underline{\text { Y-12 Sustainable Design Principles for Building Design and Construction }}$}

- If a cafeteria is to be built, design it to allow for segregated collection of steel and aluminum cans, a can crusher/compactor, and equipment associated with collection of cooking grease and food waste to be recycled.

5.a.2 Sustainable Building Practice: Waste Reduction - Minimize construction waste.

NOTE: Construction debris accounts for about $40 \%$ of the total solid waste stream of the United States, and over half the volume of U.S. landfills.

\section{5.a.2 Sustainable Building Technique(s):}

Required:

- During project's planning stage, identify local recycling and salvage operations that could process site related waste,

- Program the design to recycle or salvage at least $50 \%$ construction, demolition and land clearing waste, excluding soil, where markets or onsite recycling opportunities exist.

Other / Recommended:

- Meet requirements of LEED Materials \& Resources Credit 2.1 or 2.2: Construction Waste Management, Divert $50 \%$ or $75 \%$ from Disposal to receive up to 2 credit points toward LEED certification,

- Incorporate recycling and waste minimization requirements into construction contract/subcontract language (e.g., Y-12 Infrastructure Reduction contract agreements and contracting mechanisms incorporate language that encourages recycling by construction/demolition subcontractors),

- Encourage the separation of waste streams during the construction process to limit construction debris,

- Develop a construction waste management plan to optimize segregation, material reuse and recycling,

- Provide a dedicated area for the collection of materials for recycle,

- Reuse demolition rubble (concrete, brick, other masonry) on-site by crushing the material to stone for grading, laying utilities, and building roads, driveways and parking areas. Pulverize and reuse gravel asphalt and subbase,

- Recycle surplus commodities and by-products. Utilize material exchange programs such as Recycler's World Network (www.recycle.net) and the DOE Materials Exchange network (wastenot.er.doe.gov) to transfer unwanted materials to alternate users (in accordance with Y-12 property management requirements).

Resources for construction waste management:

- General Services Administration Construction Waste Management Database, cwm.wbdg.org. Identifies recyclers for 15 commonly recycled construction 


\section{$\underline{\text { Y-12 Sustainable Design Principles for Building Design and Construction }}$}

and demolition debris such as concrete, asphalt, masonry, metal, plastic and wood,

- Contractors' Guide to Preventing Waste and Recycling, www.resourceventure.org/publications.htm. A guidebook on waste prevention in construction from the Business and Industry Resource Venture,

- Sustainable Building Sourcebook, www.greenbuilder.com/sourcebook/ConstructionWaste.html. A guide to construction waste management.

5.b Sustainable Building Practice: Maximize use of materials with recycled content designated in the EPA Comprehensive Procurement Guidelines (CPG). Provide written justification for CPG items that are not purchased in accordance with the guidelines.

\section{5.b Sustainable Building Technique(s):}

Required:

- For EPA-designated products, use products meeting or exceeding EPA's recycled content recommendations,

- For other products, use materials with recycled content such that the sum of post-consumer recycled content plus one-half of the pre-consumer content constitutes at least $10 \%$ (based on cost) of the total value of the materials in the project,

- Incorporate EPA CPG guideline items in building design specifications, material selection, and contract documents. Table 2 lists some of the common construction items to be included,

- During construction, ensure that the actual materials installed are those that were specified in contract documents.

Other / Recommended:

- Meet requirements of LEED Materials \& Resources Credit 4.1 or 4.2: Recycled Content, $10 \%$ or $20 \%$ to receive up to 2 credit points toward LEED certification,

- Encourage use of recyclable assemblies and products that can be easily deconstructed at the end of their useful lives. 


\section{$\underline{\text { Y-12 Sustainable Design Principles for Building Design and Construction }}$}

\section{Table 2: Some of the Construction Items Included in the EPA Comprehensive Procurement Guidelines (CPG) *and USDA Designated Bio-based Products for Federal Procurement}

$\begin{array}{ll}\text { Construction Products: } & \text { Landscaping Products: } \\ \text { Insulation } & \text { Mulch } \\ \text { *Insulation foam for wall construction } & \text { Lawn and garden edging } \\ \text { Blasting grit } & \text { Compost } \\ \text { Carpet and carpet cushion } & \\ \text { *Biobased carpet } & \text { Park and Recreation Products: } \\ \text { Cement and concrete w/ fly-ash and slag } & \text { Plastic fencing } \\ \text { Latex paint (reprocessed) } & \\ \text { Floor tiles } & \text { Parking Lot / Transportation Products: } \\ \text { Patio blocks } & \text { Delineators } \\ \text { Shower and restroom dividers } & \text { Parking stops } \\ \text { Fiberboard \& Laminated paperboard } & \text { Traffic barricades } \\ \text { *Biobased composite panels } & \text { Bike racks } \\ \text { Non-pressure pipe } & * \text { Sorbents } \\ \text { Roofing materials } & * \text { Dust suppressants } \\ \text { *Biobased roof coatings } & * \text { Deicers } \\ \text { *Adhesive and mastic removers } & \\ \text { *Concrete and asphalt release fluids } & \text { Cleaners } \\ \text { *Wood and concrete sealer } & * \text { Floor strippers } \\ & * \text { Glass cleaners } \\ \text { Miscellaneous } & * \text { Bath and tile cleaners } \\ \text { Office Furniture } & * \text { Hand cleaners and sanitizers } \\ \text { *Biodegradable containers } & * \text { Grease removers } \\ & \end{array}$

Resources for environmentally preferable product ideas:

- EPA Comprehensive Procurement Guidelines, www.epa.gov/epaoswer/nonhw/procure/about.htm. A complete listing of EPA-designated items that must be purchased with recycled content in accordance with the CPG, and information on the recycled content of any material covered by affirmative procurement is provided,

- EPA database of environmentally preferable product suppliers, www.epa.gov/cpg/products.htm,

- DOE Environmentally Preferable Products Handbook, http://www.hss.energy.gov/pp/epp/EPP-DOE-Handbook-rev12.pdf provides links to listings and web-sites for recycled and bio-based products, as well as water efficient and energy efficient products,

- CIWMB Recycled Content Product Database, www.ciwmb.ca.gov/rcp. A searchable database for recycled content products, developed by the California Integrated Waste Management Board, 


\section{$\underline{\text { Y-12 Sustainable Design Principles for Building Design and Construction }}$}

- Also refer to resources listed in Sections 5.d and 5.e.

5.c Sustainable Building Practice: Maximize use of USDA-designated bio-based products.

\section{5.c Sustainable Building Technique(s):}

Required:

- For USDA-designated products, use products meeting or exceeding USDA's biobased content recommendations,

- For other products, use biobased products made from rapidly renewable resources and certified sustainable wood products,

- Incorporate USDA designated biobased products in building design specifications, material selection, and contract documents. Table 2 lists some of the common construction items that can be included,

- During construction, ensure that the actual materials installed are those that were specified in contract documents.

Other / Recommended:

- Meet requirements of LEED Materials \& Resources Credit 6: Rapidly Renewable Materials and/or Credit 7: Certified Wood to receive up to 2 points toward LEED certification,

- Use rapidly renewable / bio-based materials such as: bamboo flooring, biobased plastics (from cornstarch), wheatboard panels, wheatgrass cabinetry, sunflower seed board, and cotton batt insulation,

Resources for biobased and environmentally preferable product ideas:

- EPA database of environmentally preferable product suppliers, www.epa.gov/cpg/products.htm,

- DOE Environmentally Preferable Products homepage, www.eh.doe.gov/P2/epp/ provides links to listings and web-sites for recycled and bio-based products, as well as water and energy efficient products,

- USDA BioPreferred Federal Biobased Products Preferred Procurement Program (FB4P), www.biobased.oce.usda.gov/fb4p. Provides listings of USDA designated biobased products, compliance requirements vendor lists and success stories,

- Office of the Federal Environmental Executive Green Purchasing Biobased Products webpage, www.ofee.gov/gp/bioprod.html.

- Certified Wood and Paper Association, www.cwpa.info. Promotes environmentally responsible forest products and provides free service to architects seeking certified wood product vendors,

- Forest Certification Resource Center, www.certified wood.org. A searchable database of FSC products, 


\section{$\underline{\text { Y-12 Sustainable Design Principles for Building Design and Construction }}$}

- Also refer to resources listed in Sections 5.d and 5.e.

5.d Sustainable Building Practice: Eliminate use of ozone depleting compounds (ODC).

\section{5.d Sustainable Building Technique(s):}

Required:

- Eliminate the use of ODCs during and after construction where alternative environmentally preferable products are available (consistent with the Montreal Protocol and Title VI of the Clean Air Act Amendments of 1990, or equivalent overall air quality benefits that take into account life cycle impacts),

- Meet requirements of LEED Energy and Atmosphere Prerequisite 3: Fundamental Refrigerant Management.* ${ }^{\text {see footnote Table } 1}$

Other / Recommended:

- Meet requirements of LEED Energy and Atmosphere Credit 4: Enhanced Refrigerant Management to receive one point toward LEED certification,

- Specify HVAC, refrigeration, and fire-suppression systems and building refrigerators that contain no Class I ODC,

- Ensure construction and equipment maintenance materials such as cleaners, degreasers, and aerosols contain no ODC,

- Consult the EPA Significant New Alternatives Policy (SNAP) program (www.epa.gov/ozone/snap/index.html) for acceptable substitutes for ozonedepleting substances.

5.e Sustainable Building Practice: Use materials and equipment with less environmental impact.

\section{5.e Sustainable Building Technique(s):}

Recommended:

- Meet requirements of LEED Materials \& Resources Credits 3.1 or 3.1:Materials Reuse, $5 \%$ or $10 \%$ to receive up to 2 points toward LEED certification,

- Meet requirements of LEED Materials \& Resources Credits 5.1 or 5.1: Regional Materials, $10 \%$ or $20 \%$ to receive up to 2 points toward LEED certification,

- Use regional materials. Give preference to locally produced products and other products with low embodied energy content. Use building materials and resources that are regionally manufactured and/or incorporate as much salvaged and recycled content as possible,

- Maximize the content of recycled and bio-based materials in all purchased items, especially from a post-consumer perspective,

- Use rapidly renewable / bio-based materials such as: bamboo flooring, biobased plastics (from cornstarch), wheatboard panels, wheatgrass cabinetry, sunflower seed board, and cotton batt insulation, 


\section{$\underline{\text { Y-12 Sustainable Design Principles for Building Design and Construction }}$}

- Specify material harvested on a sustained yield basis such as lumber from certified forests,

- Encourage use of recyclable assemblies and products that can be easily deconstructed at the end of their useful lives,

- Eliminate use of materials that pollute or are toxic during their manufacture, use or reuse,

- Include selected environmentally preferable products in design specifications and contract documents. During construction, ensure that the actual materials installed are those that were specified in contract documents,

- Also see techniques listed for improving indoor environmental quality (Section 4).

Resources for environmentally preferable and resource-efficient product ideas:

- Environmental Building News, www.building green.com/products/. Site contains lists of bio-based and green building products,

- Guide to Resource-Efficient Building Elements, www.crbt.org. A directory of environmentally responsible and rapidly renewable building products (e.g., bamboo flooring),

- Oikos, oikos.com. A searchable directory of resource-efficient building products,

- Also refer to the resources listed in Sections 5.b, 5.c, and 5.d. 


\section{$\underline{\text { Y-12 Sustainable Design Principles for Building Design and Construction }}$}

\section{Summary of Sustainable Building Design Driver(s):}

This section highlights DOE Directives, Executive Orders and Y-12 plans, policies and procedures that are drivers for incorporating sustainable building practices into building design and construction. This information was obtained in part from DOE G 413.3-6 High Performance Sustainable Building which is available online at www.directives.doe.gov.

\section{a. DOE Directives:}

(1) DOE O 413.3A, Program and Project Management for the Acquisition of Capital Assets. This Order, along with its contractor requirements document, requires incorporating the Higy Performance Sustainable Building (HPSB) principles in the project management of capital asset acquisitions involving the siting, design, construction, and commissioning of new facilities and major renovations of existing facilities. The HPSB principles are defined in a January 2006 DOE Memorandum of Understanding and are further discussed in DOE G 413.3-6 High Performance Sustainable Building guide.

(2) DOE O 430.2B, Departmental Energy and Utilities Management. This Order requires the integration of DOE energy and utilities management with other DOE facilities management processes over the life cycle of a facility, and it establishes Departmental energy efficiency leadership goals. The Order contains a requirement that capital asset construction or major renovation projects attain Leadership in Energy and Environmental Design (LEED) Gold certification. (This Guide provides a process under DOE O 413.3A that enables compliance with requirements to achieve LEED Gold certification, but the Guide itself contains no requirements.) DOE O 430.2B also includes a requirement for existing buildings to incorporate the HPSB principles to support the EO 13423 goal for existing buildings. The order also requires all new construction or major renovation projects to incorporate renewable energy equipment into building design to the maximum extent feasible, requirements for reducing petroleum use by vehicle fleets and site transportation, requirements for meeting Energy Star building requirements, and for procuring EPEAT registered and FEMP-designated equipment.

(3) DOE O 450.1A, Environmental Protection Program. This Order establishes sustainable environmental stewardship goals for DOE sites to achieve through the use of Environmental Management Systems. These Departmental goals directly relate to the acquisition of environmentally preferable products (ODC-free, recycled-content, biobased, and EPEAT-registered electronic products), and recycling of construction debris provisions in the HPSB principles. DOE O 450.1A also contains requirements for implementing recycling programs in all federal facilities.

(4) The Department of Energy Acquisition Regulations (DEAR). The DEAR supplements the Federal Acquisition Regulation, which codifies uniform policies for acquisition of supplies and services by executive agencies, and contains clauses for 


\section{$\underline{\text { Y-12 Sustainable Design Principles for Building Design and Construction }}$}

inclusion in contracts. DEAR 970.5223-2, Affirmative Procurement Program, and DEAR 970.5223-1, Integration of Environment, Safety, and Health into Work Planning and Execution, support HPSB principles in the acquisition of capital assets.

\section{b. Federal Leadership in High Performance and Sustainable Buildings Memorandum of Understanding}

This January 24, 2006, Memorandum of Understanding states that the Federal government is committed to designing, constructing, and operating its facilities in an energy-efficient and environmentally sustainable manner, consistent with Federal agency missions. The Memorandum of Understanding encourages the use of life-cycle concepts, consensus-based standards, and performance measurement and verification methods that lead to sustainable buildings. The Memorandum of Understanding establishes five HPSB principles that all agencies are to follow in the design, construction and commissioning of federal buildings

\section{c. Executive Order (E.O.) 13423, Strengthening Federal Environmental, Energy and Transportation Management and its Implementing Instructions}

E.O. 13423 consolidates prior "Greening the Government” Executive Orders and integrates the sustainable practices of those orders into a cohesive approach to environmental, energy, and transportation management. Executive Order 13423 requires Federal agencies to lead by example in advancing the nation's energy security and environmental performance. One of the sustainable environmental and energy practices of Executive Order 13423 is compliance with the HPSB principles of the Federal Leadership in High Performance and Sustainable Buildings Memorandum of Understanding in the design, construction and/or major renovation, and commissioning of Federal Buildings. In addition EO 13423 sets a goal incorporating HPSB into existing buildings.

\section{d. Energy Policy Act (EPAct) of 2005, Pub. L. No. 109-58}

Section 109 of the Energy Policy Act of 2005, Federal Building Performance Standards, states that if life-cycle cost-effective, "sustainable design principles are to be applied to the siting, design, and construction of all new and replacement federal buildings.” It further states that each building project will "comply with third-party certification standards for high performance sustainable buildings.” DOE has issued regulations (10 CFR Parts 433, 434, and 435) as required by Section 109 of the EPAct that establish revised energy efficiency performance standards for new Federal buildings.

\section{e. Energy Independence and Security Act of 2007, Pub. L. No. 110-140}

The Energy Independence and Security Act of 2007, Title IV, Subtitle C-HighPerformance Federal Buildings-contains annual energy reduction goals for Federal buildings for the years 2006 through 2015. The law requires the Secretary of Energy to 


\section{$\underline{\text { Y-12 Sustainable Design Principles for Building Design and Construction }}$}

identify a green building certification system and level applicable to Federal buildings, and provide input to semiannual OMB scorecards for energy management activities.

\section{f. Office of Management and Budget Circular A-11 Guidance}

Office of Management and Budget Circular A-11 addresses, among other things, the planning, budgeting, and acquisition of capital assets. Part 7 (section 300) of this Circular requires Federal agencies to report whether "sustainable design principles" have been incorporated into the project.

\section{g.Y-12 Policies and Procedures:}

(1) Y72-001, B\&W Y-12 Environmental, Safety and Health Policy commits Y-12 to conducting work in a manner that integrates sustainability principles and practices in a safe, compliant, and cost effective manner. This policy was signed by the Y-12 president and General Manager.

(2) Y77-177, Y-12 Complex-Wide Recycling establishes recycling requirements to satisfy the EO 13423 mandate for federal facilities to initiate a recycling program. A list of items required to be recycled at Y-12 are listed on the Y-12 Sustainability and Stewardship homepage (formerly Pollution Prevention homepage).

(3) Y77-938, Y-12 Environmentally Preferable Purchasing Instruction assigns responsibilities to Y-12 Organizational Managers for implementing affirmative procurement within their organizations by ensuring that EPA-designated recycled items included in the EPA Comprehensive Procurement Guidelines (CPG) are purchased with recycled content instead of virgin materials (unless written justification is provided based on availability, performance, or cost). Requesters/Users of the items must purchase products that contain the highest percentage of recovered materials where feasible. This procedure also requires purchase of USDA Designated biobased products, Energy Star products, and DOE EPEAT certified electronics.

(4) Y-12 Storm Water Pollution Prevention Plan requires use of best management practices to preserve and protect the water quality and natural flow of storm water throughout the Y-12 Complex. The plan focuses on reducing site runoff, minimizing soil erosion and siltation, and minimizing outdoor storage of waste, chemicals, scrap metals and other materials that could negatively impact storm water quality.

(5) Y-12 Environmental Management System (EMS has established EMS objectives and targets for integrating sustainable design and sustainability practices into Y-12 operations, engineering and construction activities. 